REVIEW PAPER

\title{
Fruit and Vegetable Processing Waste Management - An Overview
}

\author{
V.K. Joshi \\ Department of Food Science and Technology, Dr Y.S. Parmar Universisty of Horticulture and Forestry Nauni, Solan, India \\ *Corresponding author: vkjoshipht@rediffmail.com
}

Paper No.: 246

Received: 09-10-2020

Revised: 23-11-2020

Accepted: 14-12-2020

\begin{abstract}
India is a country with a population of 136 crores and produces an estimated 150 million tons of fruits and vegetables, according to the Indian Agricultural Research Data Book (2004). India being an agro-economy-based country, the production is high. However, the assimilation of waste products is equally high, amounting to nearly 50 million tons. It is seen that the waste by-products, in the form of solid and liquid waste, are formed from the processing industries. This waste is not just a by-product of the remains of fruits and vegetables but is also a bioproduct, rich in nutrients like carbohydrates, protein, fat, minerals, and others. Often remains unused and underutilized, this waste also can add to the increasing pollution in the environment if not disposed of properly. In India, the food processing industry, including fruit and vegetable processing, is the second-largest generator of wastes in the environment after household sewage. This paper thus reviews how food processing industries can look into the components of utilizing the waste by-products of fruits and vegetables, opting for a stabilized and economical procedure and help in the recovery of valuable compounds, which otherwise are getting lost in vain.
\end{abstract}

Keywords: Food processing industry, waste, by-products, organic compounds, development

The processing of fruits results in generation of high amounts of waste materials such as peels, seeds, stones, pomace, rags, kernels and oilseed meals (Joshi and Attri, 2006). A huge amount of waste in the form of liquid and solid is produced in the fruit and vegetable processing industry which causes pollution problem if not utilized or disposed-off properly. The waste obtained from fruit processing industry is extremely diverse due to the use of wide variety of fruits and vegetables, the broad range of processes and the multiplicity of the product (William, 2005). Peels are the major by-products obtained during the processing of various fruits and these were shown to be a good source of various bioactive compounds which posses various beneficial effects. But, significant quantities of fruit peels (20-30\% for banana and $30-50 \%$ for mango) are discarded as waste by the processing industries which cause a real environmental problems (Zhang et al. 2005). Thus, new aspects concerning the use of these wastes as byproducts for further exploitation on the production of food additives or supplements with high nutritional value have gained increasing interest because these are high-value products and their recovery may be economically attractive. It is well known that by-products represent an important source of sugars, minerals, organic acid, dietary fibre and phenolics which have a wide range of action which includes antitumoral, antiviral, antibacterial, cardioprotective and antimutagenic activities. Natural products provide unlimited opportunities for new drug leads because of the unmatched availability of

How to cite this article: Joshi, V.K. (2020). Fruit and Vegetable Processing Waste Management - An Overview. Int. J. Food Ferment. Technol., 10(2) 67-94.

Source of Support: None; Conflict of Interest: None क्ष 
chemical diversity. Because of increasing threat of infectious diseases, the need of the hour is to find natural agents with novel mechanism of action. The solid waste from fruits and vegetables is of economic value and can be used for manufacturing of various by-products (Gray, 2006). Fruit and vegetable peels are thrown into the environment as agro-waste which can be utilized as a source of antimicrobics. Use of local resources and crop byproducts as livestock feeds is a necessary precondition for profitable production. Several by-products have potential value, especially for ruminants, due to their ability to digest fibre (Boucque and Fiems, 1988). Utilisation of by-products is, however, limited due to the poor understanding of their nutritional and economic value (Schroeder, 1999).

According to Indian Agricultural Research Data Book (2004), the estimated fruit and vegetable production in India was 150 million tones and the total waste generated was 50 million tones. The extent of total losses in these commodities is approximately estimated as $20-30 \%$ of the total production, amounting to a loss of ₹ 30,000 crore per annum. While according to FAO (2003), the total waste generated from fruits was estimated as 3.36 million tones (MT) out of the total production of 16.8 MT and particularly for banana it was 6.4 MT. India is producing 3 millions tonnes of citrus fruits like mandarins, lime, lemon, and sweet orange. Citrus wastes are rich source of oil, pectin and variety of byproducts. World production of essential oils extracted from all varieties of fruits especially citrus is about 1600 tonnes of orange oil, 25000 tonnes of lemon oil and 180 tonnes of grapefruit oil (Wright, 1995). The failure or inability to salvage and reuse such materials economically results in the unnecessary waste and depletion of natural resources (Bhalerao et al. 1989). Generally, solid waste is dumped in local landfills, eaten and scattered by stray animals. The extent of the waste produced from processing industries of some of the important fruits and vegetables, is given in Table 1.
Table 1: Quantities of various fruit and vegetable processing wastes

\begin{tabular}{ll}
\hline Commodity & Percent weight basis \\
\hline Apple & $12-47$ \\
Apricot & $8-25$ \\
Grape fruit & $3-58$ \\
Orange & 3 \\
Peach & $11-40$ \\
Pear & $12-46$ \\
Asparagus & $3.2-30$ \\
Bean, green & $5-20$ \\
Beet & $7-4$ \\
Broccoli & 20 \\
Cabbage & $5-25$ \\
Carrot & $18-52$ \\
Cauliflower & 8 \\
Peas & $6-79$ \\
Potatoes & 5 \\
Spinach & $10-40$ \\
Sweet potato & 15 \\
Tomato & $5-25$ \\
\hline
\end{tabular}

Sources: Gera IB and Kramer, 1969.

Solid waste in the form of various parts from fruits and vegetables in India (Nand, 1994) has been given in the Table 2.

About $90 \%$ of the processing units in India are small scale units. These units have no organized methods of waste disposal. In certain places, this waste is taken away by farmers for their disposal as cattle feed or field manure. This review discusses the potential of the most important by-products of fruits and vegetable processing as a source of valuable compounds.

\section{WASTE FROM FRUIT AND VEGETABLE PROCESSING INDUSTRIES}

During the preparation of various fruits and vegetable products, large quantities of solid waste material is left over unutilized which can be utilized for the manufacture of various by-products in order to reduce the cost of production besides to reducing the pollution load (Fig. 1). 
Table 2: Fruits and vegetable processing wastes available in India

\begin{tabular}{lllll}
\hline Vegetable & Nature of waste & $\begin{array}{l}\text { Production (content) } \\
\text { (tones) }\end{array}$ & $\begin{array}{l}\text { Approx. waste } \\
\text { (\%) }\end{array}$ & $\begin{array}{l}\text { Potential quantities of } \\
\text { waste (tones) }\end{array}$ \\
\hline Mango & Peel, stones & 6987.7 & 45 & 3144.4 \\
Banana & Peel & 2378.0 & 35 & 832.3 \\
Citrus & Peel, rag and seed & 1211.9 & 50 & $6-06.0$ \\
Pineapple & Skin, core & 75.7 & 33 & 24.7 \\
Grapes & Stem, skin and seeds & 565 & 20 & - \\
Guavas & Peel and core and seeds & 565 & 10 & - \\
Peas & Shell & 107.7 & 40 & 68.3 \\
Tomato & Skin, core and seeds & 464.5 & 20 & 90.3 \\
Potato & Peel & 2769.0 & 15 & 415.3 \\
Onion & Outer leaves & 1102.0 & - & - \\
Apple & Peel, pomace and seeds & 1376.0 & - & 412.0 \\
\hline
\end{tabular}

Sources: Gupta and Joshi, 2000.

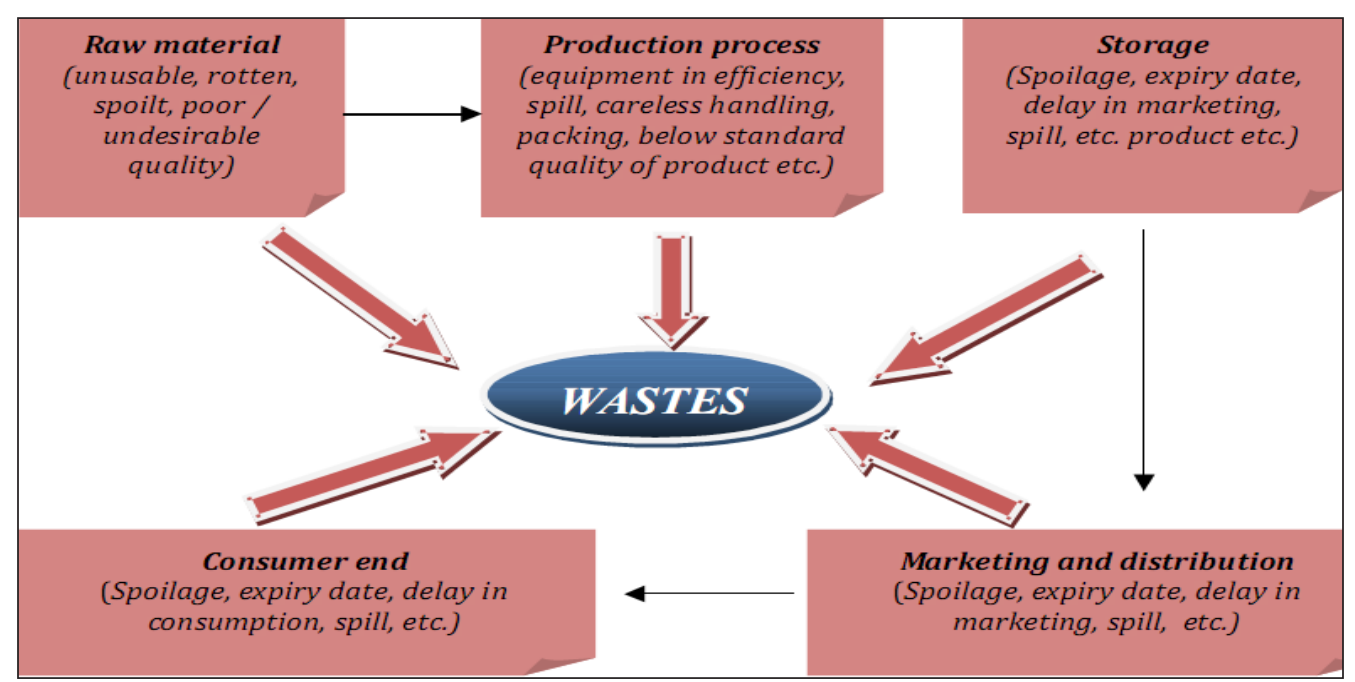

Fig. 1: Major sources of pollution load in fruit and vegetable processing industries

The major sources of waste from fruits and vegetables industry are summarized here :

\section{(a) Fruit processing wastes}

1. Peel, rag and seeds of citrus fruits

2. Pomace from apple and pear

3. Peel and stones in mangoes.

4. Rind and seeds of jack fruit

5. Core and peel in guava
6. Grape seeds

7. Over ripe and blemished fruit from canneries etc.

(b) Vegetable processing wastes

1. Tomato seeds, skins and trimmings

2. Asparagus waste from canning

3. Vines and pods form pea canning

4. Waste from canning or drying of vegetables like spinach, pumpkins, sweet potatoes and beans (Joshi and Bhutani, 1995). 


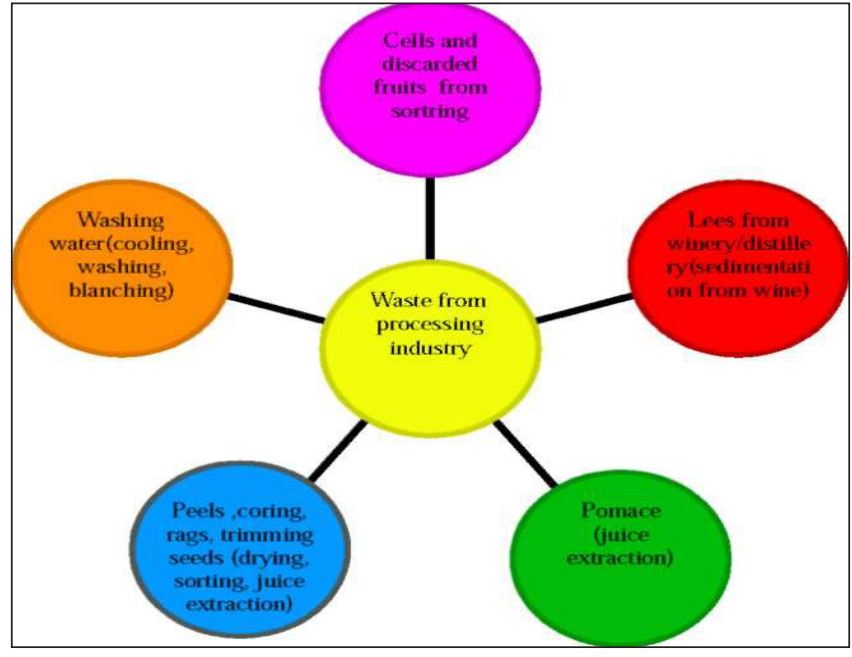

Fig. 2: Types of waste generated from fruit and vegetable processing industry

\section{CHEMICAL COMPOSITION}

The amount of pollution load and characteristics of the waste depend on the food being processed (Arrianitiyannis, 2008). Chemical composition of the wastes from fruits and vegetables show that it is a rich source of various nutrients. So, throwing the waste from food processing industries into the river is virtually throwing coins into the sea. Some of these fruit and vegetable wastes are a rich source of vital constituents like carbohydrates, proteins, fats, minerals, fibres etc. Nutrient composition of some of the solid wastes from fruits and vegetables is given in the Table 3.

\section{ENVIRONMENTAL PROBLEMS AND REGULATION}

A disposal of these materials in the environment usually represents a problem that is further aggravated by legal restrictions. Environmental legislation has significantly contributed to the introduction of sustainable waste management practices throughout the European Union. For instance, the Landfill Directive forbids disposal of untreated organic waste starting from 1.5.2005. By the year 2010, organic waste disposal has to be reduced by $80 \%$ (European Council 1999).Efficient disposal of waste can help in minimizing pollution hazards, supply of vital nutrients to our food (Harrison, 2001; Whiting, 2001). The waste also provide valuable raw material for gas reactors, organic manure and extraction of several types of useful by-products.

Table 3: Composition of different fruit wastes (per 100g)

\begin{tabular}{llllllll}
\hline Waste & Moisture $(\mathrm{g})$ & Protein $(\mathrm{g})$ & Fat $(\mathrm{g})$ & Minerals $(\mathrm{g})$ & Fibre $(\mathrm{g})$ & Carbohydrate (g) & Ref. no. \\
\hline Apple pomace & - & 2.99 & 1.71 & 1.65 & 16.16 & 17.35 & 18 \\
Mango seed kernel & 8.2 & 8.50 & 8.85 & 3.66 & - & 74.49 & 21 \\
Jack fruit (inner and outer & 8.5 & 7.50 & 11.82 & 6.50 & 30.77 & 14.16 & 35 \\
portion & & & & & & & \\
Jack fruit seeds & 64.5 & 6.60 & 0.40 & 1.20 & 1.50 & 25.80 & 16 \\
Jack seed flour & 77.0 & 2.64 & 0.28 & 0.71 & 1.02 & 18.12 & 36 \\
Passion fruit peel & 81.9 & 2.56 & 0.12 & 1.47 & 5.01 & - & 30 \\
Banana peel & 79.2 & 0.83 & 0.78 & 2.11 & 1.72 & 5.00 & 26 \\
Sweet orange seeds & 4.00 & 15.80 & 36.90 & 4.00 & 14.00 & - & 22 \\
Watermelon seeds & 4.3 & 34.10 & 52.60 & 3.70 & 0.80 & 4.50 & 16 \\
Muskmelon seeds & 6.8 & 21.00 & 33.00 & 4.00 & 30.00 & - & 33 \\
Pumpkin seeds & 6.0 & 29.50 & 35.40 & 4.55 & 12.00 & 12.53 & 23 \\
Banana stem & & & & & & & 27 \\
Central core & 93.1 & 0.30 & 0.03 & 1.04 & 0.68 & 1.20 & 27 \\
Outer hard & 91.9 & 0.12 & 0.06 & 0.98 & 1.81 & 2.44 & 27 \\
Fibrous sheath & & & & & & & 2.41
\end{tabular}


Industrial liquid waste which is being disposed off into the streams has to be made pollution free. For the disposal of this waste there are stringent standards which have been laid down by the regulatory agencies under the Water (Prevention and Control of Pollution) Act, 1974 and Environmental Protection Act, 1986 (Table 4). These standards are mandatory for the processing industries, necessitating adoption of suitable pollution control measures before the waste can be discharged (Arrianitiyannis, 2008).

The Biological Oxygen Demand (BOD) Chemical Oxygen Demand (COD) and $\mathrm{pH}$ of some of the wastes from various products are given in Table 5 .

Table 4: Standards for waste water disposal set up by environment protection agency

\begin{tabular}{ll}
\hline Parameters & Limits BOD $(\mathrm{mg} / \mathrm{L})$ \\
\hline Inland & 30.00 \\
On land & 100.0 \\
Sewage & 350.0 \\
$\mathrm{pH}$ & 5.5 \\
TDS (Total dissolved solids) (mg/L) & 9.0 \\
Total soluble solids (mg/L) & 210.0 \\
Electronic conductivity (mho) & 100.0 \\
$\mathrm{SO}_{4}(\mathrm{mg} / \mathrm{L})$ & 1000.0 \\
$\mathrm{Chloride}(\mathrm{mg} / \mathrm{L})$ & 1000.0 \\
COD (Chemical oxygen demand) $\mathrm{ppm}$ & 2000.0 \\
\hline
\end{tabular}

Table 5: Characteristics of food industry wastes

\begin{tabular}{llll}
\hline Product & COD $(\mathrm{mg} / \mathrm{L})$ & BOD $(\mathrm{mg} / \mathrm{L})$ & $\mathrm{pH}$ \\
\hline Apple & $395-37,000$ & $240-19,000$ & $4.1-08.2$ \\
Beets & $445-13,240$ & $530-06,400$ & $5.6-11.9$ \\
Carrots & $1,750-02,910$ & $817-01,927$ & $7.4-10.6$ \\
Cherries & $1,200-03,795$ & $660-01,900$ & $5.0-07-9$ \\
Green beans & $78-02,200$ & $43-01,400$ & $6.3-0.83$ \\
Peas & $729-02,284$ & $337-01,350$ & $4.9-0.92$ \\
Sauerkraut & $470-65,000$ & $300-41,000$ & $3.6-0.68$ \\
Tomatoes & $652-02,305$ & $454-01,575$ & $5.6-10.8$ \\
Wine & $4,95-12,200$ & $363-07,665$ & $3.1-09.2$ \\
\hline
\end{tabular}

Sources: Hang and Walters; 1989; Johar et al. 1960.

\section{WASTE MINIMIZATION}

The primary aim of waste legislation is the prevention of waste generation. Waste prevention refers to three types of practical actions, i.e., strict avoidance, reduction at source, and product re-use. However, waste prevention does not only include the reduction of absolute waste amounts but also avoidance of hazards and risks because safety is also of major concern. Considering the waste management options, at the top of the hierarchy stands waste minimization that includes (Riemer \& Kristoffersen 1999): waste prevention i.e. reduction of waste by application of more efficient production technologies; internal recycling of production waste; source-oriented improvement of waste quality, e.g. substitution of hazardous substances; re-use of products or parts of products, for the same or other purpose.

Solid waste from fruit and vegetable industries can be utilized for the preparation of various by-products. The possible by-products which can be prepared are given in the Table 6 as well as explained in the following head.

Table 6: Possible by-products from solid wastes in fruit processing industries

\begin{tabular}{|c|c|c|c|}
\hline $\begin{array}{l}\text { Fruit/ } \\
\text { Vegetable }\end{array}$ & $\begin{array}{l}\text { Waste } \\
(\%)\end{array}$ & $\begin{array}{l}\text { Nature of } \\
\text { waste }\end{array}$ & By-products \\
\hline Apple & $20-30$ & Pomace & $\begin{array}{l}\text { Juice, wine, vinegar, } \\
\text { pectin, cattle feed, citric } \\
\text { acid, lactic acid. }\end{array}$ \\
\hline \multicolumn{4}{|l|}{ Citrus } \\
\hline (i) Orange & 50 & $\begin{array}{l}\text { Peels, seeds } \\
\text { and pulp }\end{array}$ & $\begin{array}{l}\text { Essential oil, pectin, cattle } \\
\text { feed, peel candy etc. }\end{array}$ \\
\hline (ii) Lime & 60 & $\begin{array}{l}\text { Peels, seeds } \\
\text { and pulp }\end{array}$ & $\begin{array}{l}\text { Essential oil, pectin, cattle } \\
\text { feed, peel candy etc. }\end{array}$ \\
\hline Mango & $40-60$ & $\begin{array}{l}\text { Peel and } \\
\text { pulp }\end{array}$ & Pectin, cattle, feed, alcohol \\
\hline Peels & $12-15$ & Fibre & Wine, vinegar, juice \\
\hline $\begin{array}{l}\text { Pulper } \\
\text { waste }\end{array}$ & $5-10$ & $\begin{array}{l}\text { Hull \& } \\
\text { kernel }\end{array}$ & Fat, tannins, starch \\
\hline Kernels & $15-20$ & $\begin{array}{l}\text { Peel, core, } \\
\text { trimming, }\end{array}$ & $\begin{array}{l}\text { Juice, wine, syrup, } \\
\text { bromeline }\end{array}$ \\
\hline
\end{tabular}




\begin{tabular}{llll} 
Pineapple & $30-60$ & Shreds & Cattle feed, biogas \\
Tomato & $20-30$ & $\begin{array}{l}\text { Core, peel } \\
\text { and seeds }\end{array}$ & $\begin{array}{l}\text { Animal feed, seed oil and } \\
\text { meal }\end{array}$ \\
Potato & - & $\begin{array}{l}\text { Peel and } \\
\text { coarse } \\
\text { solids }\end{array}$ & $\begin{array}{l}\text { Animal feed, single cell } \\
\text { protein }\end{array}$ \\
\hline
\end{tabular}

Source: Bhalerao et al. 1989; Srirangrajan and Shrikhande, 1977.

\section{Essential oils}

Lime and bergamot are among the highest priced oils. The extraction method depends upon the type of juice extractor used in plant. Mandarin essential oil is extracted in small quantity at different processing units at Bangalore, Nagpur, Abohar (Punjab) and Sikkim. Mandarin oil is also extracted in small scale unit based on orange peels collected from fresh juice vending stands. Lime oil is extracted in India at Uttrayan, Jalgaon and Kodur Table 7.

Table 7: Utilization of Citrus wastes

\begin{tabular}{ll}
\hline Total production & 3 Million tonnes \\
\hline Orange waste & $50 \%$ approx \\
Lime waste & $60 \%$ approx. \\
Mandarin oil extracted & $\begin{array}{l}\text { Bangalore, Nagpur, Abohar } \\
\text { and Sikkim. }\end{array}$ \\
Lime oil extracted & $\begin{array}{l}\text { Uttarayan (MS), Jalgaon and } \\
\text { Kodur. }\end{array}$ \\
\hline
\end{tabular}

\section{Pectin}

Pectin is an important component of citrus and apple. The pectin content of the citrus waste is upto $40 \%$ of fresh weight and apple waste comprises of $20 \%$ pectin. The thick hard rind of the passion fruit can also be used for the pectin extraction. Grape can be a suitable source of commercial source of pectin. Majority of pectin produced in the world is extracted from citrus peels. Pectin is used mainly for jam making, pharmaceutical and several other industries. Two citrus processing units in Uttrayan, and Kodur are producing lime pectin in a small quantity. India is still importing about 160 tonnes of pectin valued at about ₹ 10 crores for fruit and vegetable processing industry alone. Manufacture of "Genu" pectin in
Denmark, almost commands a virtual monopoly by carrying out year round production after procuring dried citrus peels of requisite quantity from different parts of the world. Mango peels which are also available in plenty from processing factories, have also been shown to be a good source of pectin (Table 8).

Table 8: Quality of pectin obtained from different fruit source

\begin{tabular}{lllll}
\hline Fruits & $\begin{array}{l}\text { Yield \% } \\
\text { (dry wt) }\end{array}$ & $\begin{array}{l}\text { Methoxyl } \\
\text { content (\%) }\end{array}$ & $\begin{array}{l}\text { Anhydrouronic } \\
\text { acid }\end{array}$ & $\begin{array}{l}\text { Jelly } \\
\text { grade }\end{array}$ \\
\hline $\begin{array}{l}\text { Mango } \\
\text { peels }\end{array}$ & $18-19$ & 8.99 & 58.40 & 155 \\
Dashehari & $15-16$ & 8.07 & 54.60 & 175 \\
Langra & 13.0 & 9.20 & 61.12 & 200 \\
Alphonso & 15.7 & 8.31 & - & 200 \\
Totapari & 20.2 & 9.20 & 71.20 & 277 \\
Assam & - & 9.86 & 84.73 & 250 \\
lemon & & & & \\
Mandarin & - & 9.31 & 79.89 & 200 \\
Pumello & 26.5 & 6.12 & 47.05 & 350 \\
Galgal & $15-18$ & 8.40 & 59.40 & 200 \\
$\begin{array}{l}\text { Apple } \\
\text { pomace }\end{array}$ & 9.0 & 7.50 & 66.80 & 227 \\
Raw & 9.4 & 8.90 & 79.90 & - \\
papaya & & & & 75 \\
Guava & - & 3.50 & 45.10 & 150 \\
$\begin{array}{l}\text { Cashew } \\
\text { apple }\end{array}$ & - & 9.28 & 78.36 & \\
\hline
\end{tabular}

Source: Srivas and pruthi, 1976; Chaliha et al., 1963; Beerh et al., 1976; Pruthi et al., 1960.

Maximum pectin yield $21.0 \%$ was obtained on soaking finely ground and defatted mango peel in sulphuric acid solution of $\mathrm{pH} 2.5$ at $80^{\circ} \mathrm{C}$ for 120 minutes. Maximum pectin was precipitated from the extract by adding 95\% ethanol at the rate of $200 \mathrm{ml}$ litre. Anhydrogalacturonic acid and methoxyl contents of pectin obtained under these optimum conditions were $72.80 \%$ and $9.77 \%$ respectively while equivalent weight value was 943 . These chemical characteristics values of mango peel pectin were within the accepted limit of good quality pectin.

$\mathrm{pH}$ of the solution played a significant role in the extraction of pectin. Maximum amount of pectin 
$21.0 \%$ was obtained with sulphuric acid solution of $\mathrm{pH} 2.5$ at $80^{\circ} \mathrm{C}$ after 120 minutes extraction time while minimum amount of pectin $(13.45 \%)$ was obtained with hydrochloric acid solution under the same extraction conditions (Table 9). However nitric acid solution extracted $15.11 \%$ pectin from mango peels, which is comparatively more than hydrochloric acid solution of $\mathrm{pH}$ 2.5. Earlier workers also obtained variable amounts of pectin from different fruit waste materials using different mineral acids. Better extraction of pectin with sulphuric acid might be due to the presence of sulphate ions in soaking solution.

Table 9: Effect of Different Mineral Acids Solution on the Yield of Pectin (\%age)

\begin{tabular}{lcccc}
\hline Extractants & \multicolumn{3}{c}{ Extraction Condition } & Yield \\
& pH & Temp. $\left({ }^{\circ} \mathbf{C}\right)$ & $\begin{array}{l}\text { Time } \\
\text { (Minutes) }\end{array}$ & Percentage \\
\hline Hydrochloric Acid & 2.5 & 80 & 120 & $13.45 \pm 0.7$ \\
Sulphuric Acid & 2.5 & 80 & 120 & $21.0 \pm 0.5$ \\
Nitric Acid & 2.5 & 80 & 120 & $15.11 \pm 05$ \\
\hline
\end{tabular}

Mean Value - S.D. Triplicate Determinations. Source: Rehman et al. 2003.

About $7.20,11.00$ and $21.0 \%$ pectin was precipitated when ethanol was added into the filtrate at the rate of 50, 100 and $200 \mathrm{ml}$ litre per litre, respectively. Similarly, pectin yield was 5.40, 9.00 and $14.44 \%$ after the addition of acetone in the filtrate at the rate of 50, 100 and $200 \mathrm{ml}$ litre per litre respectively (Table 10). These results revealed that maximum amount of pectin $(21.0 \%)$ was obtained by the addition of ethanol at the rate of $200 \mathrm{ml}$ litre $^{-1}$.

Table 10: Effect of Different Precipitating Agent on the Yield of Pectin (\%age)

\begin{tabular}{|c|c|c|c|c|c|}
\hline 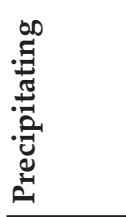 & 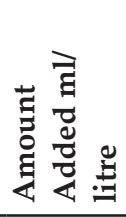 & 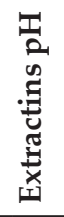 & 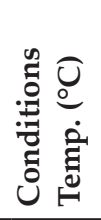 & 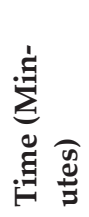 & 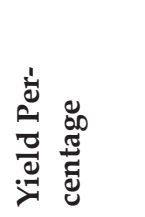 \\
\hline \multirow[t]{3}{*}{ Ethanol } & 50 & 2.5 & 80 & 120 & $7.20 \pm 0.5$ \\
\hline & 100 & 2.5 & 80 & 120 & $11.00+0.6$ \\
\hline & 200 & 2.5 & 80 & 120 & $21.0 \pm 0.8$ \\
\hline
\end{tabular}

\begin{tabular}{llllll}
\hline Acetone & 50 & 2.5 & 80 & 120 & $5.40 \pm 0.1$ \\
& 100 & 2.5 & 80 & 120 & $9.00 \pm 0.3$ \\
& 200 & 2.5 & 80 & 120 & $14.44 \pm 0.5$ \\
\hline
\end{tabular}

Mean Value - S.D. Triplicate D Determinations.

Source: Rehman et al. 2003.

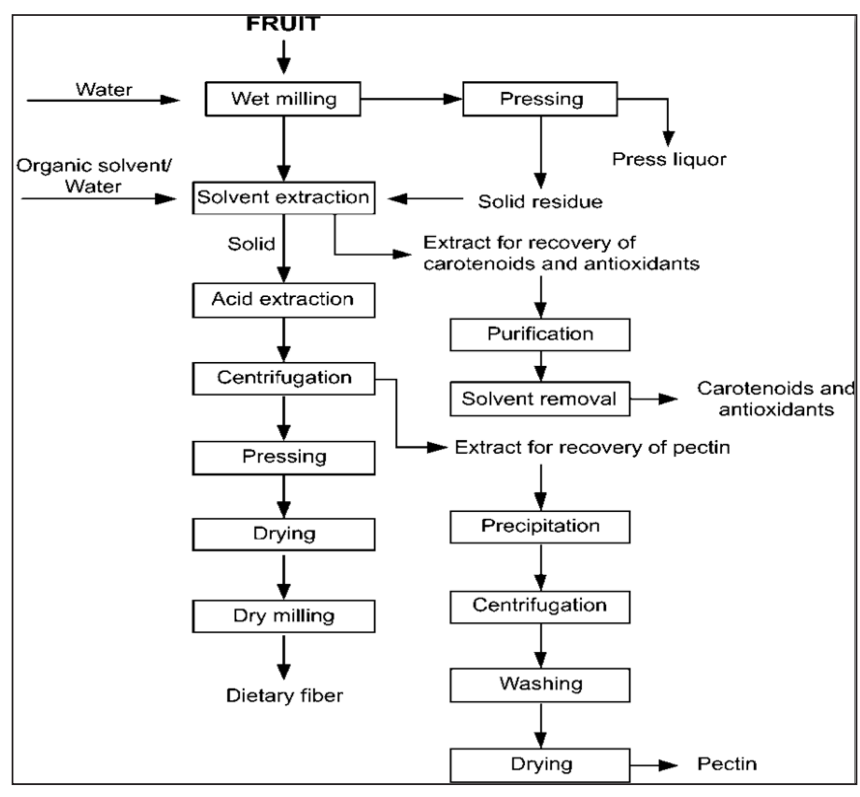

Source: Sonja et al., 2009

Fig. 3: Flow Diagram for the utilization of the fruit pomace

\section{Fat}

The stone content of mango contain 9-23\% with an average of 15\% (Palaniswamy et al. 1974). According to one estimate, 0.3 million tones of dry mango kernels are available annually from which 30,000 tonnes of mango fat valued at ₹ 20 crores, could be obtained. In 1985, 1035 tonnes of mango fat were produced although its potential is reckoned at not less than 48,000 tonnes. In case of grapes from the pomace, the seed can be separated and pressed to extract oil, which is edible in its refined state. From the waste, $10-15 \%$ of oil can be extracted. Peach and apricot kernels are used for extraction of the oil for industrial use. It is used in the pharmaceuticals and the cosmetic industry for the manufacture of the soap and cream etc. The thick hard rind of passion fruit and its seeds are used for the recovery of oil, 
respectively. The tomato seeds can be separated and utilized for the extraction of edible oil. They are the good source of proteins and amino acids.

Table 11: Present use and future potential of mango waste

\begin{tabular}{ll}
\hline Total production & Estimated waste Peels \\
\hline Pulper waste Stones & 10.0 million tonnes \\
\hline Size of total waste & \\
\hline $\begin{array}{l}\text { Uses of fruits fallen raw and } \\
\text { held wastes Pickles (1 kg per } \\
\text { family) }\end{array}$ & $6.0-36.7 \%$ \\
$\begin{array}{l}\text { Amchur from 92,500 tonnes } \\
\text { green mangoes }\end{array}$ & $12-15 \%$ \\
$\begin{array}{l}\text { Estimated availability of dry } \\
\text { mango seeds }\end{array}$ & $1,75,000$ tonnes \\
$\begin{array}{l}\text { Estimated fat content } \\
\text { Estimated value }\end{array}$ & $\begin{array}{l}37,000 \text { tonnes 3,00,000 } \\
\text { tonnes 30,000 tonnes }\end{array}$ \\
$\begin{array}{l}\text { Actual production of fat } \\
\text { Estimated availability of starch } \\
\text { from seed kernel }\end{array}$ & $\begin{array}{l}1,40,000 \text { tonnes, } 506 \\
\text { million tonnes }\end{array}$ \\
\hline
\end{tabular}

Source: Maini and Sethi, 2000

Starch

Banana pseudo-stems are used for the extraction of about 5\% edible starch. The method for starch extraction from pseudo-stems has been standardized and physico-chemical properties of starch have been studied (Subramanyam et al. 1957). Likewise, 1,40,000 tonnes of starch may also be available from mango seed kernels (Das and Banerjee, 1952).

\section{Dietry fibre}

The term 'dietary fibre' is generally understood to mean vegetable polysaccharides and lignins that retain their resistance when exposed to the influence of digestive enzymes in the human gastrointestinal tract. The health-promoting properties of dietry fibers have been recognized for several decades including their ability to bind a number of substances, including cholesterol and gastric juice (Jenkins et al. 1998) .

Dietary fibre consists of substances like cellulose, hemicellulose, lignins and pectins, resins and waxes
(Prosky 1999). Dietary fibre plays an important role in the prevention and cure of diabetes, obesity, atherosclerosis, heart diseases, colon cancer and colorectal cancer (Ferguson 2005). Hemicellulose and pectin have a remarkable capability of binding metal ions, as is the cellulose and lignin, though to a smaller extent, because the source of origin notably affects the metal binding properties of the two fractions (Nawirska 2005). Epidemiological data have revealed a causal link between civilization diseases and diets poor in dietary fibre. In developed countries, the low DF content in human diet is blamed for the development not only of civilization diseases (atherosclerosis,obesity, diabetes, tooth decay) but also of non-infectious diseases of the gastrointestinal tract (chronic constipation, appendicitis, polyps, tumors) (Rodrígez et al. 2006). To produce DFenriched preparations those parts of cereals, fruit and vegetables that are rich in non-digestible carbohydrates are used primarily. The starting materials for the production of DF preparations are bran, straw, corn cobs and chaff, as well as the byproducts or wastes from industrial processing of fruit and vegetables, i.e. apple, currant, citrus fruit, carrot, tomato, melon or spinach pomace. Their utilization is convenient and cost-effective and, what is more, enables rational management of troublesome wastes.

Process flow of insoluble dietary fiber production from apple pomace

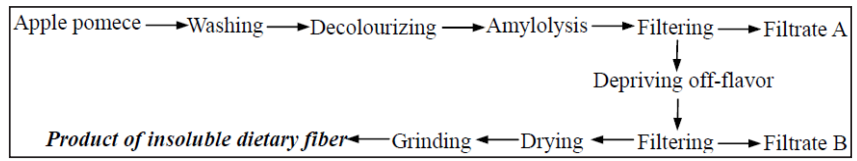

Process flow of soluble dietary fiber production from apple pomace

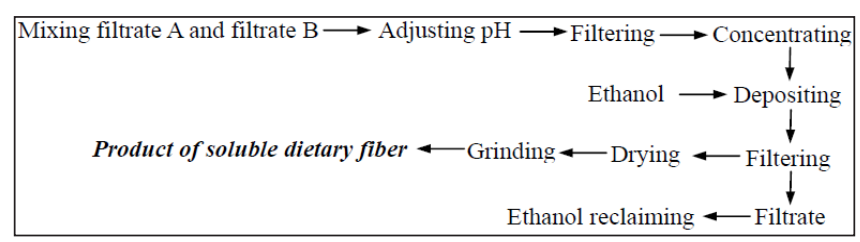

Dietry fibres are extracted from apple and pear pomace by several producers. The extraction process involves mechanical filtration, dehydration of filtered solids and screening. The apple and pear 
Table 12: Polyphenol and dietary fiber content (\%) of ripened banana and mango fruits

\begin{tabular}{llllllll}
\hline Sample & Fruit Parts & \multirow{2}{*}{ Poly-phenol } & \multirow{2}{*}{ TDF } & IDF & SDF & $\begin{array}{l}\text { IDF/TDF ratio SDF/ TDF ratio } \\
\mathbf{( \% )}\end{array}$ & $\begin{array}{l}\text { (\%) } \\
\text { Banana }\end{array}$ \\
& Pulp & $10.97 \mathrm{ba}$ & $3.54 \mathrm{bca}$ & $1.63 \mathrm{ca}$ & 1.91 & 46.04 & 53.95 \\
& Peel & $16.60 \mathrm{ba}$ & $52.11 \mathrm{dba}$ & $40.52 \mathrm{dba}$ & 11.59 & 77.75 & 22.24 \\
\multirow{2}{*}{ Mango } & Pulp & $42.02 \mathrm{dca}$ & $23.07 \mathrm{dca}$ & $10.61 \mathrm{ca}$ & 12.46 & 45.99 & 54.00 \\
& Peel & $54.45 \mathrm{dcb}$ & $73.04 \mathrm{dbc}$ & $53.59 \mathrm{dbc}$ & 19.45 & 73.37 & 26.62 \\
\hline LSD $(\mathrm{p}<0.05)$ & & $0.0213^{*}$ & $0.0134^{*}$ & $0.0192^{*}$ & $0.0159^{*}$ & & \\
\hline
\end{tabular}

Table 13: Proportion of NDF, ADF, Cellulose, Hemi-cellulose and lignin in pomace, g/100g DM

\begin{tabular}{|c|c|c|c|c|c|}
\hline Pomace & NDF & ADF & Cellulose & Hemicellulose & Lignin \\
\hline 'Idared' apple & $24.20^{\mathrm{h}} \pm 0.54$ & $19.81 \pm 1.74$ & $3.64^{\mathrm{g}} \pm 1.24$ & $4.26^{\mathrm{d}} \pm 1.45$ & $6.17^{\mathrm{f}} \pm 1.32$ \\
\hline 'Champion' apple & $31.27^{f} \pm 0.28$ & $21.90^{\mathrm{e}, \mathrm{f}} \pm 1.43$ & $16.10^{\mathrm{e}} \pm 0.90$ & $9.37^{c} \pm 1.19$ & $5.80^{\mathrm{f}, \mathrm{g}} \pm 0.98$ \\
\hline 'Ducar' strawberry & $55.19^{\mathrm{d}} \pm 0.37$ & $45.05^{c} \pm 1.38$ & $29.35^{\mathrm{b}} \pm 1.02$ & $10.13^{c} \pm 1.07$ & $15.70^{\mathrm{d}, \mathrm{e}} \pm 0.83$ \\
\hline 'Kent' Strawberry & $58.25^{c} \pm 0.67$ & $46.70^{c} \pm 0.64$ & $25.86^{c} \pm 0.78$ & $1.55^{\mathrm{e}} \pm 0.21$ & $20.84^{c} \pm 0.15$ \\
\hline Chokeberry & $87.48^{a} \pm 0.60$ & $57.24^{\mathrm{a}} \pm 2.05$ & $34.56^{\mathrm{a}} \pm 1.26$ & $30.24^{\mathrm{a}} \pm 0.82$ & $22.68^{\mathrm{b}} \pm 0.25$ \\
\hline Black currant & $63.55^{b} \pm 0.66$ & $47.67^{\mathrm{b}} \pm 0.94$ & $21.01^{\mathrm{d}} \pm 0.88$ & $15.87^{\mathrm{b}} \pm 0.32$ & $26.66^{\mathrm{a}} \pm 0.11$ \\
\hline 'Black' Carrot & $28.55^{\mathrm{g}} \pm 0.62$ & $23.57^{\mathrm{e}} \pm 0.52$ & $16.28^{\mathrm{e}} \pm 0.91$ & $4.98^{\mathrm{d}} \pm 0.12$ & $7.29^{f} \pm 1.06$ \\
\hline 'Dolanka' Carrot & $18.05^{\mathrm{i}} \pm 0.69$ & $16.02^{\mathrm{g}} \pm 0.75$ & $12.65^{f} \pm 0.91$ & $2.03^{\mathrm{e}} \pm 0.22$ & $3.37^{\mathrm{h}} \pm 0.86$ \\
\hline Red cabbage & $34.76^{\mathrm{e}} \pm 0.87$ & $29.33^{\mathrm{d}} \pm 1.04$ & $15.21^{\mathrm{e}} \pm 0.89$ & $5.43^{\mathrm{d}} \pm 0.27$ & $14.12 \mathrm{e} \pm 0.65$ \\
\hline
\end{tabular}

*Mean of three replications; if different within a column, indicates significant difference (CD 0.05).

pomace contains $56 \%$ and $75 \%$ fibres, respectively. The product prepared from fruit dietary fibre having same consistency as that of wheat and used in manufacturing of bread, baked foods cereals, and in pharmaceuticals (Morris, 1985). On laboratory scale, fibres from apple pomace have been extracted by solvent extraction (Walter et al. 1985).

\section{Fruit juices and syrup}

Peels and cores from apple and pear processing plant used in manufacturing of fruit juice. Pectinase enzymes are used to facilitate juice recovery by depectinization. The pomace left after extraction of cane berry juice is used in manufacturing of cane berry sauce. Orange peels, sliced and blanched are used in preparation of marmalade.

Acids

Various acids such as citric acid, lactic acid and vinegar can be produced using the waste residues from different fruit and vegetables.
Citric acid can be prepared from lime, lemon, apple, galgal etc. The juice is first fermented naturally to remove gum, pectin and sugars which hinders its filtration. The fermented juice is then treated with filter aid at $60^{\circ}$ to $66^{\circ} \mathrm{C}$ and then filtered. Hydrated lime and calcium carbonate are added to precipitate the calcium citrate. The precipitates are separated and dried quickly to avoid discoloration. It is then, treated with conc. $\mathrm{H}_{2} \mathrm{SO}_{4}$ to decompose the citrate into citric acid. From the apple pomace the citric acid can be produced by the citric acid producing fungal strains of Aspergillus niger. Apple pomace has proved to be a good substrate for citric acid production.

Process flow of citric acid production from apple pomace

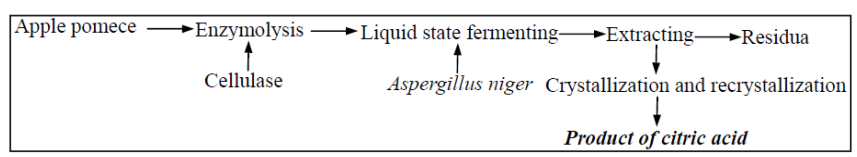

From unfermented juice, calcium citrate may be prepared and strong solution of sodium carbonate is added to form sodium citrate. The precipitated 
calcium carbonate prepared can be filtered of and concentrated to crystallize to form sodium citrate (Hang et al. 1977).

Apple pomace as a raw material for lactic acid manufacture has advantages, like high content of free glucose and fructose, that are excellent carbon sources for lactic acid production, high content of polysaccharides (cellulose, starch and hemicelluloses) that can be enzymatically hydrolysed to give monosaccharides, presence of other compounds (monosaccharides different from glucose and fructose, di- and oligo-saccharides, citric acid and malic acid) that can be metabolised by lactic bacteria and the presence of metal ions ( $\mathrm{Mg}, \mathrm{Mn}, \mathrm{Fe}$, etc.) that could limit the cost of nutrient supplementation for fermentation media.

\section{Wines}

The wastes from grape processing plants are used in the manufacture of alcoholic beverages. The extract from seeds of raisins can be fermented with yeast and distilled to obtain ethyl alcohol or brandy. The alcoholic content is about $10 \%$. The seeds can be washed with warm water to dissolve sugar from the adhering pulp and syrup. The solution, which contains sugar and other grape solid can be filtered and concentrated in a vacuum pan and condensed to certain density for the production of brandy.

Cider is a prepared from apple juice by fermentation. The alcoholic content is about $1-8 \%$. Apple pomace has been utilized for the production of cider (Johar et al. 1960). The brandy can also be prepared from apple pomace (Masuda, 1964).

\section{Vinegar}

It is also been prepared from fruit waste by alcoholic fermentation and then, the Acetobacter bacteria are used for acetic acid production. It can be prepared by Orleans slow process or German quick process. It can also be produced by mixing apple pomace with molasses in ratio 2:1 (Joshi and Joshi, 1990). Vinegar production from orange peel has also been made successfully (Gera and Kramer, 1969). The peel and core of the pear can be fermented in alcoholic beverages called 'Perry' which can be converted into fruit vinegar by further acetic fermentation. Pineapple vinegar also made to small extent in India.

\section{Colours}

From ancient times, natural colours have been used to give food an attractive appearance. The addition of synthetic colours to food products has become a controversial subject because of their toxic effect and have been banned in some cases. Natural colour and nature-identical colours such as p-carotene, chlorophyll and anthocyanin are used. The extracts of colours from fruit waste can be used in fruits and vegetable industry. The important colours are orange red from carotenoids and dark red from anthocynanins.

About $70 \%$ of carotenoids of the whole citrus fruit are concentrated in flavedo. The main component are xanthophylls, but these depend upon ripeness, soil condition and other factors (Gross, 1977). The extraction of carotenoids is not easy because they are insoluble in water. There are many ways for extraction of colour from wet peels (Ting and Herdrickson, 1969). The terpene like $d$-limonene is added to the mixture in order to absorb the readily extracted caroteniods. After centrifuging the solid particles, the liquid is again centrifuged to remove $d$-limonine, which contains $75 \%$ of carotenoids present in the flavedo. The oil phase is dewatered, concentrated and purified to about 36\% solution of carotenoids (Kanna et al. 1984). Extraction of color from dried citrus peel, flakes are shredded and treated with lime to a $\mathrm{pH} 8.0$ to 9.0. They are then, pressed and dried in rotating drier with a directly heated drum in which temperature is carefully controlled to avoid over-heating. The dried peel is stored in cool silo and colour extraction is done as soon as possible to prevent loss of carotenoids.

Anthocyanins are present in many dark coloured fruits which are sensitive to heat, metals, $\mathrm{pH}$ and air. The concentration of colour in grapes depends upon the temperature during ripening. The most abundant 
colour pigment in grape is melvidin 3-acetyl glucoside which is found mainly in the skin of the fruits.

Fruits like plum also have anthocyanin, as their pigment especially in the skin. Pomace produced as waste from processing of plum is a rich source of pigment. Technology for production of biocolours from plum has been optimized and a flow sweet for the process is depicted in Fig. 4.

\section{Microbial pigments}

Food colors are used for increasing appeal of food by making them more attractive. But synthetic colours have adverse effect on health so their use in colouring foods is of great concern. Microorganisms like Rhodotorula, Sarcina Cryptococcus, Phaffia rhodozyma, Monoascus purpureus and Bacillus spp are used for the production of pigment by fermentation of waste from fruits \& vegetable industries (Joshi et al. 2003). Rhodotorula used for the production of carotenoids pigment

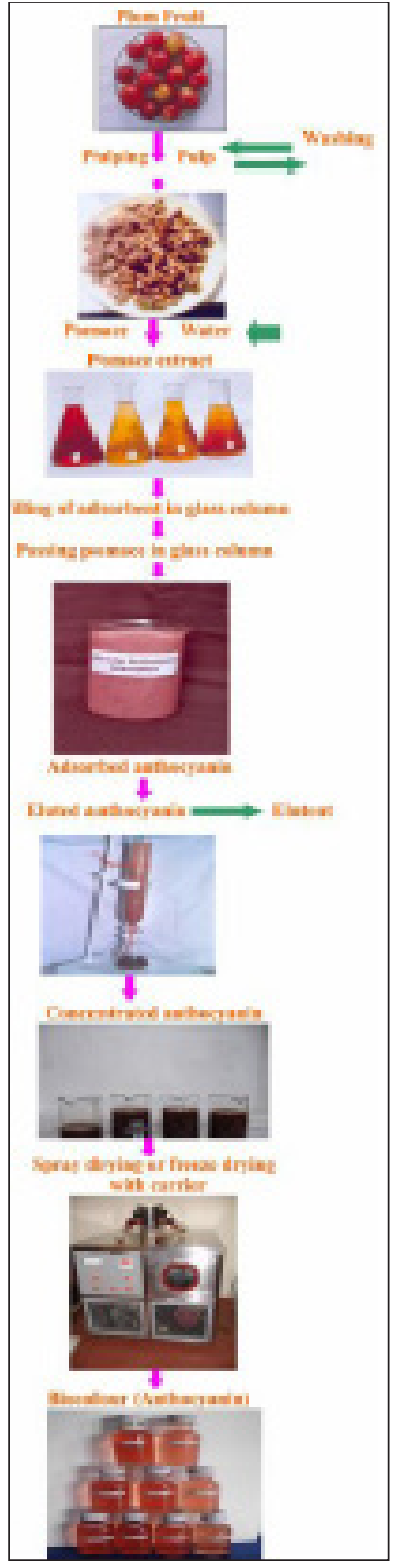

Fig. 4 from apple pomace (Joshi and Attri, 2005; Joshi and Rana, 2008) using solid state fermentation. Moreover, microbial colours have been found to have antineoplastic activity (Nair, 1994).

Apple pomace due to presence of several nutrients proved to be a good component of medium to produce microbial pigments. It has been utilized for the production of microbial colours using SSF. It has been used successfully for cultivation of Rhodotorula for pigment production (Sandhu and Joshi 1997; Joshi and Attri, 2005). The effect of carbon and nitrogen sources on yield and carotenoids production by Chromobacter sp. a dark red colour producing bacteria showed that apple pomace at a concentration of $20 \mathrm{~g} / \mathrm{l}$ gave maximum yield of biomass and carotenoids in the basic medium. The use of maltose $(0.3 \%)$ in the apple pomace based medium produced the maximum yield of biomass $(6.65 \mathrm{~g} / \mathrm{l})$ and carotenoids $(46.33 \mathrm{mg} / 100 \mathrm{~g})$. Amongst the different nitrogen sources tried, potassium nitrate $(0.1 \%)$ gave the maximum production of biomass $(6.50 \mathrm{~g} / \mathrm{l})$, carotenoids $(46.60 \mathrm{mg} / 100 \mathrm{~g})$ and beyond this concentration, both yield and carotenoids were reduced. A pH value, 6.0 was found optimum, whereas a temperature of $35^{\circ} \mathrm{C}$ produced the highest carotenoids with incubation period of $48 \mathrm{~h}$. The use of $50 \mathrm{~g} / \mathrm{l}$ of apple pomace in the medium gave the highest yield of biomass and carotenoids. Maltose $(0.2 \%)$ was the best carbon source. A pH range of 5.5 to 6.0 was optimized whereas a temperature of $30^{\circ} \mathrm{C}$ and incubation period of $72 \mathrm{hrs}$ produced the highest amount of carotenoids. 10-50g/L of apple pomace have been incorporated to the basic medium for the producton of Rhodotorula (pink colour) Sarcina sp. (dark yellow), Chromobacter sp. (dark red). The production of pigment in apple pomace based medium using SSF Micrococcus gives the better yield of biomass and carotenoids. Rhodotorula sp. has been best grown at a temperature of $30{ }^{\circ} \mathrm{C}$ for 72 hours at pH 5.5 in the apple pomace based medium whereas Chromobacter sp producing dark red colour, grew best at temperature $35^{\circ} \mathrm{C}$ with $\mathrm{pH}$ of 6.0 for 48 hours. Pigment production from Sarcina and Micrococcus have also been optimized (Attri and Joshi, 2005 and Joshi et al. 2007). 


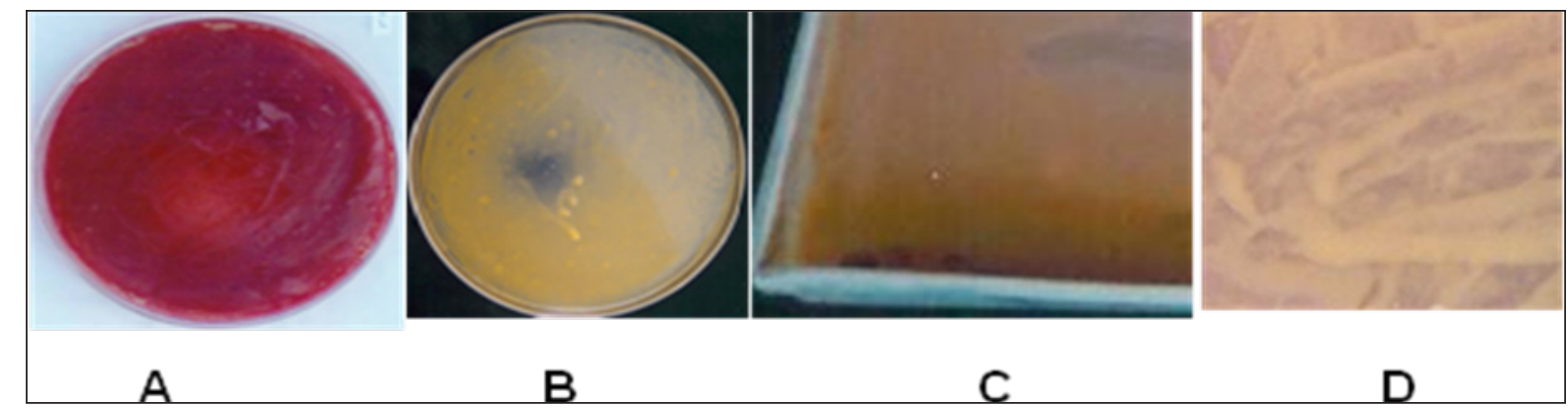

$A=$ Chromobacter sp. on a petriplate; $B=$ Sarcina sp. on a petri-plate; $C=$ Rhodotorula sp. in tray; $D=$ Micrococcus sp. in tray.

Fig. 5: Colour producing microorganisms grown on apple pomace based medium

\section{Flavour}

Microbes are used to prepare flavours from the fruit and vegetables waste. The specific aroma and flavour like fruity, spicy, pyrazines, terpenes, lactones and esters are produced from waste by fermentation and the availability of microbial products have been cheap and renewable (Nair, 1994).

\section{Gums}

Microbial gums like Xanthan can also be produced from the waste. Cabbage waste is utilized for the production of Xanthan by Xanthomonas compestris (Lilly et al. 1958). The other sources of xanthan are molasses, grains, hydrolyzed lactose from cheese whey.

\section{Enzymes}

Fruits and vegetable waste are used for the production of various enzymes (Table 14) like invertase form sauerkraut waste by fermenting with Candida utilis. From baked beans fungal amylase has been produced (Gupta and Joshi, 2000). Dried apples are used for the production of cellulose and xylanase by Trichoderma viridae and Aspergillus spp. (Joshi et al. 1999).

Apple pomace has proved to be a good substrate for production of many enzymes like amylase, xylanase, pectinases and cellulose (Bhalla and Joshi, 1993). Production of pectinase from apple pomace is promising due to several advantages like easy availability of cheaper raw material and easier processing of the substrate. Pectinase enzymes include pectin methylesterase (pectin esterase) and depolymerising enzyme polygalacturonase and lyases). Pectin esterase hydrolyses the pectin to methanol and polygalacturonic acid (Broeck et al. 1999) and the enzyme polygalacturonase further hydrolyses the polygalacturonic acid into monogalacturonic acid by breaking the glycosidic linkage (Sakellaris et al. 1988). Pectinase is produced by several fungi including Aspergillus sp., Botrytis cinerea, Fusarium moniliforme, Rhizoctonia solani, Rhizopus stolonifer, Trichoderma sp., Neurospora crassa, etc., but Aspergillus is the major source (9). Among pectinases, pectin esterase (E.C. 3.131.11) is the first enzyme of pectin hydrolysis that catalyses the hydrolysis of methylated carboxylic ester group in pectin into pectic acid and methanol (Joshi et al.). In solid state fermentation of apple pomace with Aspergillus, 1:3 dilution $(\mathrm{w} / \mathrm{v})$ at $\mathrm{pH} 4.0$, incubation temperature of $25^{\circ} \mathrm{C}$ for 96 hours was found optimum for higher PME production (Parmar 2004). Ammonium sulphate @ 0.2 per cent and sodium chloride @ 0.5 per cent gave the highest PME production. The SSF gave 2.3 times higher PME activity than SmF. Enzymes like amylase, xylanase and cellulase have been produced from apple pomace as a substrate.

The evaluation of pectinases done in plum, peach, pear and apricot showed that the juice recovery of enzymatically treated pulp increased significantly depending upon the type of pulp and improved phsico chemical characteristics and sensory quality of enzymatically extracted juices. The maximum production of cellulase (5 units) and xylanase $(4.2$ 
Table 14: Production of enzymes from processing waste by fermentation

\begin{tabular}{|c|c|c|}
\hline Waste & Microorganisms utilized & Enzyme produced \\
\hline Apple pomace & $\begin{array}{l}\text { Trichoderma viride Aspergillus spp. T. reesei } \\
\text { A. niger Pleurotus spp. T. reesei A. phoenicis } \\
\text { Cerrena unicolor }\end{array}$ & Cellulase, Xylanase and Ligninase \\
\hline Agro wastes & $\begin{array}{l}\text { Candida utilis A. phoenicis Cerrena unicolour } \\
\text { Coriolus hirsutus Pleurotus ostreatus }\end{array}$ & Invertase \\
\hline Bagasse & Cellulase Xylanase Cellulase & B-glucosidase \\
\hline $\begin{array}{l}\text { Grape wine trimming dust Sauerkraut } \\
\text { waste Sugar beet pulp Tea production } \\
\text { waste }\end{array}$ & $\begin{array}{l}\text { Cellulase \& B-glucosidase Cellulase \& } \\
\text { Xylanase Cellulase }\end{array}$ & CMCase, Xylanase and Laccase \\
\hline
\end{tabular}

Table 15: Food processing waste used as SCP/animal feed after microbial fermentation

\begin{tabular}{ll}
\hline Waste & Microorganisms utilized \\
\hline Apple pomace & Saccharomyces cerevisiae, Candida utilis, Torula utilis, Aspergillus niger \\
Soy bean & Rhizopus oligosporus \\
\hline
\end{tabular}

Source: Nigam and Singh, 1996.

units) was obtained by the use of Trichoderma viride and Aspergillus niger, respectively. The potential of apple pomace as a substrate for the production of $\beta$-fructofuranosidase synthesis by $A$. fumigatus, $A$. foetidus and $A$. niger was studied by Hang and Woodams (1994).

Table 16: Functional properties of produced yeast SCP biomass

\begin{tabular}{ll}
\hline $\begin{array}{l}\text { Parameter Value } \\
\text { (Mean } \pm \text { S.D) }\end{array}$ & $\begin{array}{l}\text { Parameter Value } \\
\text { (Mean } \pm \text { S.D) }\end{array}$ \\
\hline Water holding capacity $(\%)$ & $303.40 \pm 0.30$ \\
Oil absorption capacity $(\%)$ & $196.50 \pm 0.20$ \\
Foaming capacity $(\%)$ & $10.60 \pm 0.20$ \\
Loose bulk density $(\mathrm{g} / \mathrm{mL})$ & $0.65 \pm 0.01$ \\
Packed bulk density $(\mathrm{g} / \mathrm{mL})$ & $0.66 \pm 0.01$ \\
\hline
\end{tabular}

Sources: Bacha et al. 2011.

\section{Single cell proteins}

The single cell protein based on the microbial growth and microbial biomass and can be used as protein supplement for feed or food (Girujie et al. 1992). A number of micro-organism (Table 15) like yeast, fungi, algae and bacteria can be employed for the production of SCP and each of them has its own advantages and disadvantages. The wastes are used for the growth of the micro-organism as starting material for fermentation and SCP production by assimilation (Flickiger and Taso, 1978).

Apple pomace is a rich source of nutrients like carbohydrates, dietary fibre, minerals, and vitamin C (Joshi, 1998). It contains pectin (12.7\%), lignin (12.8\%), hemicelluloses $(5 \%)$, cellulose $(17.6 \%)$, and starch (17.9\%) (Kennedy et al. 1999). Beside these apple pomace contains several mineral nutrients, including carbon $(44.56 \%)$, oxygen $(44.78 \%)$, hydrogen $(6.18 \%)$, chlorine $(1.02 \%)$, and nitrogen $(0.57 \%)$ (Kennedy et al. 1999). SCP can be prepared from apple pomace by Trichomonas viride and Aspergillus niger under SSF and LSF condition. Apple pomace having high lingocellulose and protein content can be co-cultured with yeast and mold fermentation in SSF (Bhalla and Joshi, 1994). Grape waste used as a substrate for Aspergillus niger to generate $35 \%$ crude proteins and cellulose. Citrus and pineapple waste has also been utilized to generate SCP by using Fusarium (Bahar and Azueze, 1984) Cassava is a carbohydrate rich substance but it is poor in protein. The protein content of cassava upto $20 \%$ by using Aspergillus niger has been achieved. It has also been treated concomitantly for producing 
SCP using Endomycopsis fibuliger and Candida utilis (Lal et al. 1991). Aspergillus tamari has been employed to produce SCP from sugar beet pulp on a pilot scale with the protein content of about $22.4 \%$ in 48 h (Gray and Abou-el-Seound, 1966). Mixed cultures of Trichoderma and yeasts, and a combination of Kluyveromyces maximas efficiently converted beet pulp into protein and offered a maximum yield of 51\% (Ghanem, 1992).

Waste from fermentation industry e.g. sauerkraut brine with high BOD and salt content has successfully been used for the growth of a number of yeasts even in non-sterile conditions but Candida utilis was preferred most as it gave higher yield in a short time. This process does not need $\mathrm{pH}$ adjustment and nutrient addition, and can remove 90\% BOD within 24 hours (Hang et al. 1977). Saccharomyces cerevisiae and Torulopsis utilis have been successfully grown on the molasses with protein yield of $42-47 \%$ and $36-38 \%$, respectively. With addition of corn steep liquor, the protein yield increased to 60 and $52.6 \%$, respectively. Saccharomyces cerevisiae had $50 \%$ protein, $2.5 \%$ fat and $13 \%$ minerals while Torulopsis utilis had $42 \%$ protein, $5.6 \%$ fat and $15.8 \%$ minerals.

The waste from brewery and distilleries also supported the production of SCP (Gera and Kramer, 1969). It can also be produced from baked bean waste using Aspergillus fotidus. Potato peels contained significantly highest dry matter and carbohydrate content as compared to other wastes. Symba-yeast on potato waste has successfully been propagated (Skogman, 1976). When two yeasts i.e. Saccharomcyes fibuliger and C. utilis were grown symbiotically, the BOD was reduced to $90 \%$ with a yeast yield of $300 \mathrm{~kg} /$ hl with $48 \%$ protein.

Potato peels supplemented with $0.04 \%$ ammonium chloride have also been used for the production of protein by using a non-toxic fungi Pleorotus ostreatus (Kahlon and Arora, 1986). Similarly, waste from orange, sugarcane and grape processing industry have also been utilized for the production of SCP (Nicolini et al. 1987 and Nigam, 1990).

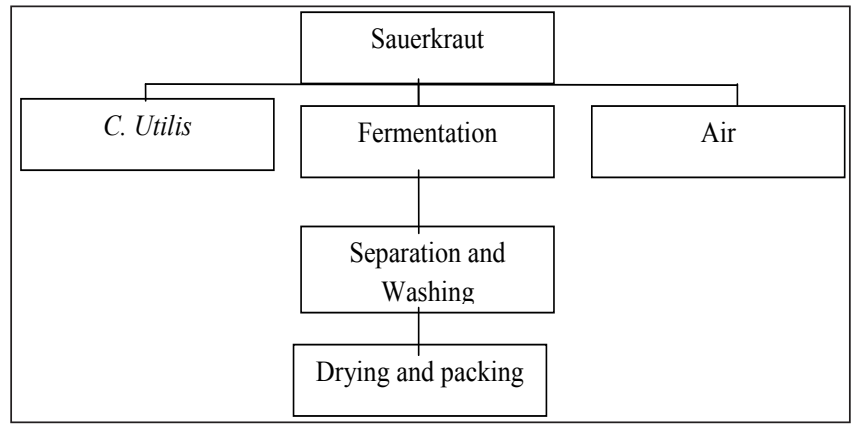

Fig. 5: SCP production From Sauerkraut.

\section{Amino acids}

The amino acids used as additive in the food, feed and as a flavouring agent have been produced from the waste. Bacteria like Coryenebacterium, Glutamicum, Arthobacter and Brevibacterium falavum are used for the manufacture of glutanmic acid, starch solution, cane molasses and beet molasses are used as substrate. Glutamic acid in the form of monosodium glutamate or ajinomoto is used as flavouring agent in food. Lysine is also manufactured by fermenting cane molasses, beet molasses or starch hydrolysis using bacteria Coryenebacterium glutamicum. It is used as salt form in bread and cookies and not synthesized in human body and used in animal feed (Marwaha and Arora, 1999).

\section{Vitamins}

Bacteria like Pseudomonas denitrificans, Propionibacterium shermanii and Streptomycetes have been used for commercial production of vitamin $B_{12}$ from waste like soyabean meal, corn steep liquor, fish meal, meat extract, etc. Corn steep liquor has also been used as a substrate for a mold Ashbya gossypii to produce vitamin $B_{2}$ or riboflavin. $\beta$-carotene which is a precursor of vitamin $\mathrm{A}$, and also as a pigment used in food industry, can be produced by microbial fermentation, using fungus Blackeslea trispora and algae Dunaliell (Marwaha and Arora, 1999).

\section{Phytochemicals}

Nowadays, there is a growing interest in finding phytochemicals as an alternative to synthetic sub- 
stances, which are commonly used in the food, pharmaceutical and cosmetic industry. Clinical studies support the role of the plant food phytochemicals as health-promoting functional food components. This idea is supported by the consumer's concern about the safety of products containing synthetic chemicals because these synthetic molecules are suspected to cause or promote negative health effects. Recent studies showed that the phytochemicals in fruits and vegetables are the major bioactive compounds with human health benefits. Epidemiological studies have pointed out that the consumption of fruits and vegetables imparts health benefits, e.g. reduced risk of coronary heart disease and stroke, as well as certain types of cancer. Apart from dietary fibre, these health benefits are mainly attributed to organic micronutrients such as carotenoids, polyphenols, tocopherols, vitamin $\mathrm{C}$ and others. Flavonoids from fruits and vegetables probably reduce risks of diseases associated with oxidative stress, including cancer. Apples contain significant amounts of flavonoids with antioxidative potential.

Both cultivated and wild berries are unpolluted and low in energy, and they are also an important source of antioxidant vitamins and fibre. Berries also contain different bio-active components, such as phenolic phytochemicals (flavonoids, phenolic acids, polyphenols) (Hakkinen et al. 1999).

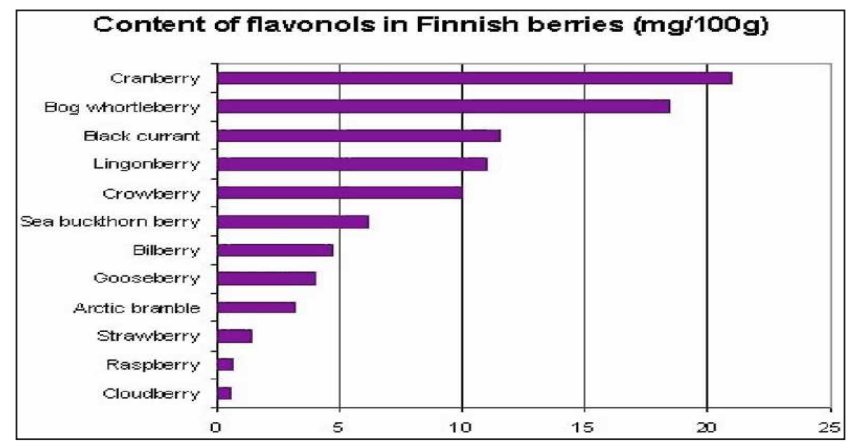

Fig. 6: Flavonol content of Finnish berries (Hakkinen et al. 1999)

It has been established that consumption of fruits rich in phytochemicals helps to avoid coronary heart disease (Hertog et al. 1993), stroke (Keli et al. 1996) and lung cancer (Knekt et al. 1997). Notable are also the antibacterial properties of berries. The cloudberry (Rubus chamaemorus), raspberry (Rubus idaeus), and bilberry (Vaccinium myrtillus) and crowberry (Empetrum nigrum) were effective against all of the bacterial strains tested. Bog bilberry (V. uliginosum) inhibited all the gram-positive bacteria, but not gram-negative $E$. coli, S. aureus, B. subtilis and M. luteus (Rauha et al. 2000). Fig. 6 shows the flavonoid content of different Finnish berries.

\section{Antioxidants}

There is some evidence that chronic diseases, such as cancer and cardiovascular disease, may occur as a result of oxidative stress (Kelly et al. 2003). The consumption of food rich in natural antioxidants, as well as food enriched with them, ensure the desirable antioxidant status and helps in prevention of the development of diseases caused (linked) by oxidative stress. The role of antioxidant phytochemicals in the prevention of these diseases has been mainly attributed to the prevention of LDL oxidation through a scavenging activity against peroxyl and hydroxyl radicals (Djilas et al. 2009). Apple peels have high concentrations of phenolic compounds and may assist in the prevention of chronic diseases. Phenolics are a much diversified group of secondary plant metabolites, which includes simple phenolic, phenolic acids (benzoic and cinnamic acid derivatives), lignans, lignins, coumarins, flavonoids, stilbenes, flavonolignans and tannins. Many of phenolic compounds have shown strong antioxidant properties as oxygen scavengers, peroxide decomposers, metal chelating agents, and free radical inhibitors. Besides antioxidant activity, phenolic compounds have a wide range of action which includes antitumoral, antiviral, antibacterial, cardioprotective, and antimutagenic activities (Djilas et al. 2009). Apple pomace has been shown to be a good source of polyphenols which are predominantly localized in the peels and are extracted into the juice to a minor extent. A conventional apple juice production (straight pressing of apple pulp or pressing after pulp enzyming) resulted in a juice poor in phenolics and with only $3-10 \%$ of the antioxidant activity of the fruit they were produced from (Sluis et al. 2002). Polyphenols are one of the phytochemical groups 
whose "protective" properties include antioxidant, antimicrobial, anticancer and cardiovascularprotective activities (Bendini et al. 2006). Different in vitro model systems were employed to evaluate the antioxidant properties of apple pomace polyphenols. For example, $\mathrm{Lu}$ and Foo determined DPPH and superoxide ion radical scavenging activities of apple pomace polyphenols, and also their antioxidant property in the $\beta$-carotene/linoleic acid system. The polyphenols examined were epicatechin, its dimer (procyanidin B2), trimer, tetramer and oligomer, quercetin glycosides, chlorogenic acid, phloridzin and 3-hydroxy-phloridzin. All the compounds showed strong antioxidant activities, and their DPPHscavenging activities were 2-3 times and superoxide anion radical-scavenging activities were 10-30 times better than those of the antioxidant vitamins $\mathrm{C}$ and $\mathrm{E}$. The antiradical activity of apple pomace was tested by measuring their ability to scavenge DPPH and hydroxyl radicals by ESR spectroscopy. The highest DPPH $($ EC DPPH $50=6.33 \mathrm{mg} / \mathrm{ml})$ and hydroxyl $($ EC $\mathrm{OH} 50=26.11 \mathrm{mg} / \mathrm{ml}$ ) radical scavenging activities were obtained in the case of Reinders pomace. The total phenolics, total flavonoids, total flavan3-ols, and some individual phenolic compounds contributed significantly to the antiradical activities of apple pomace (Ćetković et al. 2008).

The extraction of crushed grape pomace with a mixture of ethyl acetate and water yielded phenolic compounds displaying antioxidant activities comparable to BHT in the Rancimat test. Catechin, picatechin, epicatechin gallate and epigallocatechin were the major constitutive units of grape skin tannins (Souquet et al. 1996). A new class of compounds, aminoethylthio-flavan-3-ol conjugates, has been obtained from grape pomace by thiolysis of polymeric proanthocyanidins in the presence of cysteamine (Torres et al. 2001). The antioxidant activity of the extracts obtained from grape by-products was analyzed by different in vitro tests: scavenging of the stable DPPH radical,reactive $\bullet \mathrm{OH}, \mathrm{O}_{2} \bullet$ - and of authentic peroxynitrite (ONOO-). For example, Lacopini $e t$ al. evaluated the extracts obtained from skin and seeds of 10 native Tuscan and international
Vitis vinifera varieties for their antioxidant activity and subjected to HPLC-UV analysis to quantify the content of five phenolic constituents of biological interest: catechin and epicatechin in seeds and quercetin, rutin and resveratrol in skin extracts. All the five phenols investigated possessed strong antiradical activity. Quercetin, catechin and epicatechin showed maximum activity (respectively, IC DPPH• 50 5.5, 6.7 and $6.8 \mathrm{M}$, and IC ONOO50 48.8, 55.7 and $56.7 \mathrm{M})$. Mandić et al. obtained grape seed extracts (GSEs,) from Italian and Rhine Rieslings and examined their antioxidant activities using ESR spectrometry. IC50 values were between 0.1016 and $0.0445 \mathrm{mg} / \mathrm{ml}$ for the stable DPPH radicals in ethanol and ethyl acetate extracts of Italian (I-i and II-i) and Rhine (I-r and II-r) Rieslings, and for the very reactive $\mathrm{OH}$ radicals they were between 0.2759 and $0.0352 \mathrm{mg} / \mathrm{ml}$. Recent reports indicate a wide range of biological activities, e.g. radioprotective effects, the prevention of cataract antihyperglycemic effects the enhancement of postprandial lipemia, the modulation of the expression of antioxidant enzyme systems, the inhibition of the protein kinease activity of the epidermal growth factor receptor, protective effects against oxidative damage in mouse brain cells , and anti-inflammatory effects. The high efficiency of natural phenolic extracts obtained from grape seeds as potent antioxidants was confirmed, by the fact which encourages the prospect of their commercialization as natural powerful antioxidants in foods in order to increase the shelf life of food by preventing lipid peroxidation and protecting from oxidative damage. Many of the grape seed products are commercially available. Flavonoids from citrus that have been extensively studied for antioxidative, anti-cancer, anti-viral, and anti- inflammatory activities, effects on capillary fragility, and an observed inhibition of human platelet aggregation (Miyake et al. 1997). Recent research suggests that citrus fruits possess another health benefit phytochemicals called limonoids, highly oxygenated triterpenoid. Citrus limonoids appear in large amounts in citrus juice and citrus tissues as water soluble limonoid glucosides or inseeds as water insoluble limonoid aglycones. The limonoid aglycones are responsible 
for the development Currently limonoids are under investigation for a wide variety of therapeutic effects such as antiviral, antifungal, antibacterial, antineoplastic and antimalarial. Certain limonoids are insecticides such as azadirachtin from the neem tree. Most recently several limonoid aglycones and a mixture of limonoid glucosides were administered in vitro to estrogen dependent and estrogen independent human breast cancer cell lines (Jacob et al. 2000).

\section{Antimicrobics}

Several mechanisms have evolved in microorganisms, which confer them with antimicrobial resistance. Three mechanisms predominate in antimicrobial resistance: (1) enzymatic inactivation of the antimicrobial agent, (2) substitutions, amplifications or modifications of the drug target reducing the affinity of the drug to the target or (3) reduced access of the antimicrobial agents to the target by means of permeability barriers or efflux pumps (Sundsfjord et al. 2004; Fluit et al. 2001). These mechanisms can either chemically modify the antibiotic, or it becomes inactive through physical removal from the cell, or modify target site so not recognized by the antibiotics.

The antimicrobial constituents are present in all parts of the plant viz. bark, stalks, leaves, fruits, roots, flowers, pods, seeds, stems, latex, hull and fruit rind. Recent research has revealed that fruit peels and seeds, such as grape seeds and peels (Jayaprakasha et al. 2003), pomegranate peel (Singh et al. 2002), wampee peel (Prasad et al. 2010) and mango seed kernel (Kabuki et al. 2000) may potentially possess antimicrobial property.

The fruit and vegetable peel extracts showed better antifungal activity than antibacterial activity; Gramnegative bacteria were more susceptible than Grampositive bacteria which contradict the previous reports that plant extracts are more active against Gram positive bacteria than Gram negative bacteria (Rabe et al. 1997). The Gram-positive bacteria contain a single outer peptidoglycan layer, which is not an effective permeability barrier (Costa et al. 2008). The most susceptible organism was fungi $C$. glabrata and Gram-negative K. pneumoniae. M. indica showed maximum and best antimicrobial activity (Table 17).

Table 17: Antimicrobial activity of some plant peels against some microorganisms causing infectious diseases

\begin{tabular}{|c|c|c|}
\hline Plant name & Extract & Microorganisms \\
\hline $\begin{array}{l}\text { Citrus grandis } \\
\text { (Rutaceae) }\end{array}$ & $\begin{array}{l}\text { Hexane, ethyl acetate, butanol, } \\
\text { methanol, benzene: acetone }\end{array}$ & $\begin{array}{l}\text { Bacillus subtilis, Bacillus cereus, Staphylococcus aureus, Escherichia coli, } \\
\text { Salmonella enteritidis }\end{array}$ \\
\hline $\begin{array}{l}\text { Citrus reticulata Blanco } \\
\text { (Rutaceae) }\end{array}$ & Oil & $\begin{array}{l}\text { Alternaria alternata, Rhizoctonia solani, Curvularia lunata, Fusarium } \\
\text { oxysporum,Helminthosporium oryzae }\end{array}$ \\
\hline Vitis vinifera (Vitaceae) & $80 \%$ ethanol & $\begin{array}{l}\text { Staphylococcus aureus, Bacillus cereus Escherichia coli, Salmonella infantis, } \\
\text { Campylobactercoli }\end{array}$ \\
\hline $\begin{array}{l}\text { Citrus reticulate Blanco } \\
\text { (Rutaceae) }\end{array}$ & Flavonoid extract & $\begin{array}{l}\text { Escherichia coli, Staphylococcus aureus, Staphylococcus epidermidis, } \\
\text { Enterococcus faecalis, Salmonella typhimurium, Enterobacter cloacae }\end{array}$ \\
\hline $\begin{array}{l}\text { Citrus acida Roxb. } \\
\text { (Rutaceae) }\end{array}$ & Oil & $\begin{array}{l}\text { Bacillus subtilis, Bacillus cereus, Staphylococcus aureus, Escherichia coli, } \\
\text { Enterobacter aerogenes, Salmonella typhimurium, Aspergillus ficuum, } \\
\text { Aspergillus niger, Aspergillus fumigatus, Aspergillus flavus, Fusarium } \\
\text { saloni, Fusarium oxysporum, Pencillium digitatum,Candida utilis }\end{array}$ \\
\hline $\begin{array}{l}\text { Ficus carica L. } \\
\text { (Moraceae) }\end{array}$ & Aqueous & $\begin{array}{l}\text { Bacillus cereus, Staphylococcus epidermidis, Staphylococcus aureus, } \\
\text { Escherichia coli,Pseudomonas fluorescens }\end{array}$ \\
\hline $\begin{array}{l}\text { Citrus bergamia Risso } \\
\text { (Rutaceae) }\end{array}$ & Ethanolic fraction & $\begin{array}{l}\text { Escherichia coli, Pseudomonas putida, Salmonella enterica, Listeria innocua, } \\
\text { Bacillus subtilis, Staphylococcus aureus, Lactobacillus lactis, Sacharomyces } \\
\text { cerevisiae }\end{array}$ \\
\hline
\end{tabular}


Nephelium lappaceum Ether, methanol, aqueous

L. (Sapindaceae)

Musa sapientum (Musaceae)

Trapa natans L.

(Trapaceae)
Chloroform, ethyl acetate, aqueous

Petroleum ether, 1,4-dioxan, chloroform, acetone, dimethylformamide, ethanol, aqueous
Escherichia coli, Klebsiella pneumoniae, Pseudomonas aeruginosa, Salmonella typhi, Vibrio cholerae, Enterococcus faecalis, Staphylococcus aureus, Staphylococcus epidermidis

Staphylococcus aureus, Bacillus subtilis, Bacillus cereus, Salmonella enteritidis, Escherichia coli

Bacillus cereus, Micrococcus flavus, Staphylococcus aureus, Alcaligenes faecalis, Klebsiella aerogenes, Klebsiella pneumoniae, Proteus mirabilis, Proteus morganii, Pseudomonas putida, Pseudomonas testosteroni, Candida albicans, Candida albicans, Cryptococcus luteolus, Trichosporon beigelii, Aspergillus candidus, Aspergillus flavus

Sources: S. Chanda, Baravalia Y, kaneria M.

Table 18: Examples of functional food components

\begin{tabular}{|c|c|c|}
\hline Class/components & Source & Potential benefit \\
\hline \multicolumn{3}{|c|}{ Carotenoids } \\
\hline \multirow{2}{*}{$\begin{array}{l}\text { Beta-carotene Lutein, } \\
\text { Zeaxanthin }\end{array}$} & \multirow{2}{*}{ Various fruits Citrus } & $\begin{array}{l}\text { Neutralizes free radicals which may damage cells; bolsters } \\
\text { cellular ntioxidant defences. }\end{array}$ \\
\hline & & May contribute to the maintenance of healthy vision. \\
\hline \multicolumn{3}{|c|}{ Flavonoids } \\
\hline Anthocyanidins & $\begin{array}{l}\text { Berries, cherries, red } \\
\text { grapes }\end{array}$ & $\begin{array}{l}\text { Bolster cellular antioxidant defences; may contribute to the } \\
\text { maintenance of brain function }\end{array}$ \\
\hline $\begin{array}{l}\text { Flavanols - catechins, } \\
\text { epicatechins, procyanidins }\end{array}$ & Apples, grapes & May contribute to the maintenance of heart health \\
\hline Flavanones & Citrus foods & $\begin{array}{l}\text { Neutralize free radicals which may damage cells; bolster } \\
\text { cellular antioxidant defences }\end{array}$ \\
\hline Flavonols & Apples & $\begin{array}{l}\text { Neutralize free radicals which may damage cells; bolster } \\
\text { cellular antioxidant defences }\end{array}$ \\
\hline Proanthocyanidins & $\begin{array}{l}\text { Cranberries, apples, } \\
\text { strawberries, grapes, } \\
\text { wine, peanuts, cinnamon }\end{array}$ & $\begin{array}{l}\text { May contribute to the maintenance of urinary tract health } \\
\text { and heart health }\end{array}$ \\
\hline
\end{tabular}

\section{Organic compounds}

SSF technique has been used to produce organic compounds like butanol, acetone, citric acid, acetic acid and lactic acid from molasses (Gera and Kramer A,1969). The 2,3 butylene glycol can be produced by fermenting citrus peel juice and citrus waste after adding molasses (Long and Patrick, 1961).

\section{GASES}

\section{Methane gas}

Processing of wet residues to produce methane gas has been done at laboratory scale to digest tomato, peach and honey-dew solid waste (Hills \& Roberts, 1982).

\section{Biogas}

Biomass consisting of agricultural, forest, crop residues, solid and liquid wastes from industries, sewage and sludge can be utilized for production of biogas through microbial technology. The waste from fruit and vegetable processing industries being rich in biodegradable substances has been used for production of biogas. Biogas is produced by anaerobic digestion of fruit and vegetable wastes (Knol et al. 1978). Methanotropic bacteria like Methanobacterium 
and Methanococus spp. can utilize $\mathrm{CO}_{2}$ from food waste materials to produce methane (Nand, 1994). During this process, the complex polymers are first hydrolyzed into simple substances by acid forming bacteria and finally these are digested anaerobically by the Methanotropic bacteria and methane gas is liberated. Pretreatment of the waste with selected strains of Sporotrichum, Aspergillus, Penicillium, Fusarium etc. resulted in increased methane production, as they are capable of breaking complex polymers (Trehan., 1990).

The waste material from various processing industries like food, agriculture, fruits and vegetables processing industry can be also subjected to anaerobic treatment process (AnTP) for biogas production. A process is described in which stirred tank reactors are used for the treatment of waste water from industries. By this process when sugar beet pulp waste was loaded @ $1 \mathrm{~kg}$ volatile solids $\mathrm{m}^{-3} \mathrm{~d}^{-1}$, it yielded $0.74 \mathrm{~m}^{3}$ of biogas per $\mathrm{kg}$ of loading (Joshi and Joshi, 1990). Waste water from food industry under anaerobic conditions can also be utilized for biogas production, using immobilized microbial cells in a bioreactor. This technique has several benefits like continuous reactor operation at any desired input, increased productivity, easy cell/liquid separation, coarse screening of rapid gravity settling, repeated batch operation using the same cells and enhanced gas-liquid mass transfer. Fluidized Bed Bio-Reactor (FBGR) is a common immobilized bioreactor used in the anaerobic treatment of food industry waste.

\section{Catalytic gasification of wet residues}

The nickel metals are used for the gasification of metals and the process is carried out on $360^{\circ} \mathrm{C}$ and 300 psi in laboratory and 3000 psi convert $99 \%$ of COD and $10 \%$ lactose solution in $5 \mathrm{~min}$. The product of process is fuel gas containing methane, carbon monoxide and hydrogen which can be burnt in furnace (Eliot et al. 1993).

\section{Boiler fuel}

The stone shells of stone fruits and olive can be burnt in fluidized bed burner to produce steam (Anonymous, 1977). Charcoal from peach, apricot and olive pits are prepared by burning under low oxygen conditions and used as boiler fuel (Simons et al. 1994).

\section{Ethanol}

Fruits processing residues like rejects of sorting and liquid waste that contain sugar can be converted to ethanol through fermentation. Ethanol is used as transport fuel however; its production is expensive process involving fermentation and distillation. The waste from processing industry like cellulose and hemicelluloses are readily fermented by anaerobic bacteria for ethanol production. Apple, pear and cherry waste have also been utilized for the production of ethanol (Badger and Brodwer, 1989). Orange peels after enzymatic hydrolysis and fermentation by using Saccharomyces cerevisiae was suitable for ethanol production (Grohmann et al. 1994). The pineapple juice is fermented into alcohol for use in automobiles.

Many agricultural raw materials rich in fermentable carbohydrates have been tested worldwide for bioconversion from sugar to ethanol, but the cost of

Table 19: Productivity profile and composition of gas from fruit waste biomethanation

\begin{tabular}{|c|c|c|c|c|c|c|c|c|c|}
\hline \multirow{2}{*}{ Phase } & \multirow{2}{*}{$\begin{array}{l}\text { Digestion } \\
\text { period } \\
\text { (days) }\end{array}$} & \multirow{2}{*}{$\begin{array}{l}\text { Initial } \\
\text { solids in } \\
\text { the feed } \\
(\%)\end{array}$} & \multirow{2}{*}{$\begin{array}{l}\text { Gross volume } \\
\text { of the digester } \\
\text { (L) }\end{array}$} & \multirow{2}{*}{$\begin{array}{l}\text { Working } \\
\text { volume of the } \\
\text { digester }(\mathrm{L})\end{array}$} & \multirow{2}{*}{$\begin{array}{l}\text { Daily gas } \\
\text { generation } \\
\text { (L) }\end{array}$} & $\begin{array}{l}\text { Productivity } \\
\left(\mathrm{m}^{3} \text { gas } / \mathrm{m}^{3}\right)\end{array}$ & $\begin{array}{l}\text { Productivity } \\
\left(\mathrm{m}^{3} \text { gas } / \mathrm{m}^{3}\right)\end{array}$ & \multirow{2}{*}{$\begin{array}{l}\text { Methane } \\
\text { (\%) }\end{array}$} & \multirow{2}{*}{$\begin{array}{l}\text { Carbon } \\
\text { dioxide } \\
(\%)\end{array}$} \\
\hline & & & & & & $\begin{array}{l}\text { Working } \\
\text { volume }\end{array}$ & $\begin{array}{l}\text { Digester } \\
\text { volume }\end{array}$ & & \\
\hline 1 & 20 & 3 & 5 & 4 & 0.256 & 0.04 & 0.06 & $60-70$ & $30-40$ \\
\hline 2 & 20 & 4 & 5 & 4 & 1.100 & 0.20 & 0.27 & $63-75$ & $25-37$ \\
\hline 3 & 20 & 5 & 5 & 4 & 1.420 & 0.28 & 0.35 & $63-74$ & $26-37$ \\
\hline 4 & 25 & 5 & 5 & 4 & 0.060 & 0.01 & 0.01 & - & - \\
\hline
\end{tabular}


carbohydrate raw materials has become a limiting factor for large scale production by the industries employing fermentation processes. Since, the price of feedstock contributes more than $55 \%$ to the production cost, inexpensive feedstocks such as lignocellulosic biomass and agri-food wastes, are being considered to make bioethanol competitive in the open market (Arrianitiyannis, 2008).

These fruit processing wastes can be used as potential feedstock for bioethanol production and this could also be an attractive alternate for disposal of the polluting residues (Beerh et al. 1976). Few research articles deal with different practical applications of these fruit wastes (Bhalerao et al. 1989), and production of alcohol. Laboratory experiments were conducted to evaluate the chemical composition of fruit wastes (pulp and peels) of Banana and Mango in order to explore their potential application in bio-ethanol production. The dilute acid $\left(\mathrm{H}_{2} \mathrm{SO}_{4}\right)$ pretreatment (DAP) followed by enzymatic hydrolysis showed maximum reducing sugar yield of $64.27 \%$ in the mixed fruit pulps, followed by the banana fruit pulp $(57.58 \%)$. The banana fruit peels also yielded a maximum reducing sugar content of $36.67 \%$ where as the lowest of $31.29 \%$ was observed in mango fruit peels. The fermentation of the DAP hydrolysate of mixed fruit pulps showed maximum ethanol production of $35.86 \%$ corresponding to a fermentation efficiency of $70.31 \%$ at $48 \mathrm{hr}$ of incubation. Similarly, the hydrolysates obtained from the dilute $\mathrm{H}_{2} \mathrm{SO}_{4}$ pre-treated banana fruit peels yielded a maximum of $13.84 \%$ ethanol with a fermentation efficiency of $27.13 \%$ at $42 \mathrm{~h}$ of incubation. The study by Arumugam and Manikandan revealed that the fermentation of hydrolysates obtained from the dilute acid pretreatment followed by enzymatic saccharification of mixed fruit pulps (banana and mango) and the banana fruit peels were found to be the best for higher ethanol production at optimized conditions.

\section{Fertilizer and soil conditioners}

Fertilizer supply the growing plant with essential nutrients while soil conditioners produce physical and chemical changes that enhance plant growth. Residues can be utilized as fertilizers when used in well-designed and properly managed land application to suit the fields. The program should consider the field fertility nutrient requirement of planted crop and nutrient application history to sustain the quality of the soil.

\section{Animal feed}

Solid waste from fruit processing plant is valuable feed source for the animal which is rich in many nutrients as compared to other wastes. Byproduct feeds are classified as energy feed and protein feed (Bath, 1981). Ruminants are capable of fermenting fibrous material such as cellulose to various metabolic compounds. This ability makes it possible for ruminants to utilize fibres that are of little value to humans. The ruminants convert this waste into milk and meat which are valuable human foods (Huber, 1981).

The pomace left in juice plants of apple, grapes and cranberries etc can be used as animal feed. Fermented potato waste has been successfully tried as an animal feed. When sweet potato waste was fermented with fungi, their protein content increased upto $31.6 \%$. Fresh or dried apple pomace can be used as an animal feed (Hang and Walters, 1989). Milching cows have been fed with apple pomace in combination with other fodders (Shah and Masoodi, 1984). Apple pomace after fermentation with different yeasts and drying becomes enriched with proteins, vitamins, minerals and fats, and it can be used for feeding animals (Joshi et al. 1999). When apple pomace is subjected to SSF with Candida utilis there was 2.5 fold increases in protein content 3.4 fold increase in niacin, 2.0 fold increase in pantothenic acid and 1.5 fold increase in thiamin (Joshi \& Sandhu, 1996). Co-culture of apple pomace with Candida utilis and Aspergillus niger results in protein enrichment (Bhalla and Joshi, 1994). An increase in true protein from 3.4 to $7.5 \%$ took place when apple pomace was fermented with Kloeckera apiculata and Candida utilis (Rahmat et al. 1995). Furthermore, protein obtained was rich in limiting amino acid lysine. 
Table 20: Effect of pretreatment and enzymatic hydrolysis on reducing sugar yield ( $\% \mathrm{w} / \mathrm{w})$ and ethanol production $(\% \mathrm{w} / \mathrm{w})$ in the fruit samples

\begin{tabular}{|c|c|c|c|c|c|c|c|}
\hline \multirow[t]{2}{*}{ Sample } & \multirow[t]{2}{*}{ Fruit Parts } & \multicolumn{2}{|c|}{$\begin{array}{c}\text { Reducing sugar content } \\
(\% \mathrm{w} / \mathrm{w})\end{array}$} & \multicolumn{2}{|c|}{$\begin{array}{l}\text { Maximum ethanol } \\
\text { content }(\% \mathrm{w} / \mathrm{w})\end{array}$} & \multirow{2}{*}{$\begin{array}{l}\text { Fermentation } \\
\text { efficiency }(\%)^{\mathrm{b}}\end{array}$} & \multirow{2}{*}{$\begin{array}{l}\text { Ethanol Productivity } \\
(\% \text { w/w h-1) }\end{array}$} \\
\hline & & LHW + ES & $\mathrm{DAP}+\mathrm{ES}^{\mathrm{b}}$ & LHW + ES & $\mathrm{DAP}+\mathrm{ES}^{\mathrm{b}}$ & & \\
\hline \multirow[t]{2}{*}{ Banana } & Pulp & $53.93^{\text {cea }}$ & $57.58^{\text {ceab }}$ & $21.36^{\mathrm{bac}}$ & $28.45^{\text {cae }}$ & 55.78 & 0.593 \\
\hline & Peel & $22.56^{\mathrm{dfb}}$ & $36.67^{a}$ & $8.66^{\text {edf }}$ & $13.84^{\mathrm{dfb}}$ & 27.13 & 0.330 \\
\hline \multirow[t]{2}{*}{ Mango } & Pulp & $13.84^{\mathrm{dfb}}$ & $55.18^{\text {ceab }}$ & $19.62^{\mathrm{bac}}$ & $26.50^{\text {caeb }}$ & 52.00 & 0.552 \\
\hline & Peel & $20.48^{\mathrm{dfb}}$ & $31.29^{\mathrm{b}}$ & $7.82^{\text {edf }}$ & $9.68^{\mathrm{dfb}}$ & 18.96 & 18.96 \\
\hline \multirow[t]{2}{*}{ Mixed fruit } & Pulp & $56.38^{\text {cea }}$ & $64.27^{\text {ceadf }}$ & $28.72^{\mathrm{adb}}$ & $35.86^{\text {caed }}$ & 70.33 & 0.747 \\
\hline & Peel & $25.57^{\mathrm{dfb}}$ & $33.90^{\mathrm{b}}$ & $8.32^{\text {edf }}$ & $11.94^{\mathrm{dfb}}$ & 23.40 & 0.284 \\
\hline LSD $(p<0.05)$ & & $0.0208^{*}$ & $0.0376^{*}$ & $0.0224^{*}$ & $0.0137^{*}$ & & \\
\hline
\end{tabular}

All data are the mean of three replicates. Mean value followed by different letters in the same column differs significantly; Results obtained by Liquid hot water pretreatment followed by enzymatic saccharification; Results obtained by Dilute acid pretreatment followed by enzymatic saccharification.

Source: R. Arumugam and M. Manikandan

Waste from wineries, breweries and distilleries after fermentation can also be used for feeding livestock. Animal feed can also be obtained from grape pomace and wine lees after growing microbes on them. It was reported that dry brewer's grains after addition of molasses become a very good cattle feed. Apple pomace after fermentation with Torula utilis, Candida utilis, Saccharomyces cerevisiae, Schizoh, pombe and Kloeckera spp. was fed to the broilers. The fermented apple pomace when mixed with standard broiler feed in the ratio of 1:1, was acceptable to broilers with no adverse effect on body weight gain and various biochemical parameters. The results indicated that formulation of the feed could make apple pomace as one of the constituents of the broiler feed (Joshi et al. 1999).

Tomato pulp and pomace from tomato processing waste have been converted into as animal feed. The apricot cake which is left after extraction of oil is rich in protein and can be used as cattle feed. The press cake of grape is suitable for stock feed by mixing with bran or alfa-alfa meal to reduce the tannin and crude fibre content of mixture at the time of feeding. The pressed cake of pineapple can be utilized for the animal feed. The vines and pea hulls can be dehydrated and used as feed by blending it with suitable materials. The waste left after drying vegetables like potatoes, cabbage, cauliflower, turnips, carrots etc. can be used for making cattle feed.

The nutritive value of Brassica species is influenced by the high water content (i.e., $8.6 \%$ dry matter (DM) in cabbage and $10.1 \%$ DM in cauliflower (Gupta et al. 1993), which negatively affects intake. The DM, however, is rich in protein. For example cauliflower contains $20.8 \%$ crude protein (CP) (Gupta et al. 1993).

The effects of feeding Brassica vegetable market wastes on intake, body weight changes and pesticide/insecticide residues in products of goats were evaluated by feeding four diets with leaves either from cabbage (Brassica oleracea var. capitata), cauliflower (Brassica oleracea var. botrytis) or Chinese cabbage (Brassica campestris subsp. pekinensis) with $30 \%$ of Para grass. The control group was fed 100\% Para grass. All diets contained soybean waste as a supplement and the experiment lasted for 136 days. The goats were fed cabbage waste supplemented with $200 \mathrm{~g}$ or $100 \mathrm{~g}$ DM (dry matter) of concentrate. Para grass with $100 \mathrm{~g}$ DM concentrate supplementation was used as a control group. Due to low DM content (5.3 and 3.7\%, respectively) feed intakes of cabbage and Chinese cabbage groups were lower than those of other groups in the experiment. The highest feed intake and body weight gain was obtained when 
Table 21: Effect of diets on daily live weight gain

(LS-means and SE)

\begin{tabular}{|c|c|c|c|c|c|c|c|c|c|}
\hline & \multirow{2}{*}{$\begin{array}{l}\mathrm{ChC}+\mathrm{PG} \\
+\mathrm{SB}\end{array}$} & \multicolumn{3}{|c|}{ Exp.1, diets } & \multirow[b]{2}{*}{ SE } & \multirow{2}{*}{$\begin{array}{l}C+ \\
200 \text { Con }\end{array}$} & \multicolumn{2}{|c|}{ Exp. 2, diets } & \multirow[b]{2}{*}{ SE } \\
\hline & & $\begin{array}{l}\mathrm{C}+\mathrm{PG} \\
+\mathrm{SB}\end{array}$ & $\begin{array}{l}\mathrm{CF}+\mathrm{PG}+ \\
\mathrm{SB}\end{array}$ & $P G+S B$ & & & $\begin{array}{l}\text { PG + } 100 \\
\text { Con }\end{array}$ & $\begin{array}{l}C+100 \\
\text { Con }\end{array}$ & \\
\hline Initial weight $(\mathrm{kg})$ & 9.5 & 9.2 & 9.3 & 9.6 & 0.2 & 13.3 & 12.6 & 13.3 & 0.81 \\
\hline Final weight $(\mathrm{kg})$ & $18.0^{\mathrm{b}}$ & $19.1^{\mathrm{b}}$ & $21.2^{\mathrm{a}}$ & $18.3^{b}$ & 0.4 & 20.2 & 20.6 & 19.6 & 1.06 \\
\hline BWG (g/day) & $62.8^{c}$ & $73.4^{\mathrm{b}}$ & $87.5^{\mathrm{a}}$ & $64.0^{c}$ & 2.7 & 76 & 88 & 70 & 5.6 \\
\hline FCR (kg DM/kg BWG) & $4.5^{\mathrm{c}}$ & $4.5^{\mathrm{c}}$ & $6.0^{\mathrm{b}}$ & $6.7^{\mathrm{a}}$ & 0.3 & 6.5 & 7.6 & 6.6 & 0.4 \\
\hline
\end{tabular}

$a, b, c$ Means within rows and experiment with different superscripts are significantly different $(p<0.05)$.

BWG: body weight gain; FCR: feed conversion ratio; CHc: Chinese cabbage Brassica oleracea var. capitata; C: cabbage Brassica oleracea var. botryti; CF: cauliflower Brassica campestris subsp. Pekinensis; PG: para grass; SB: soybean waste; Con: concentrate.

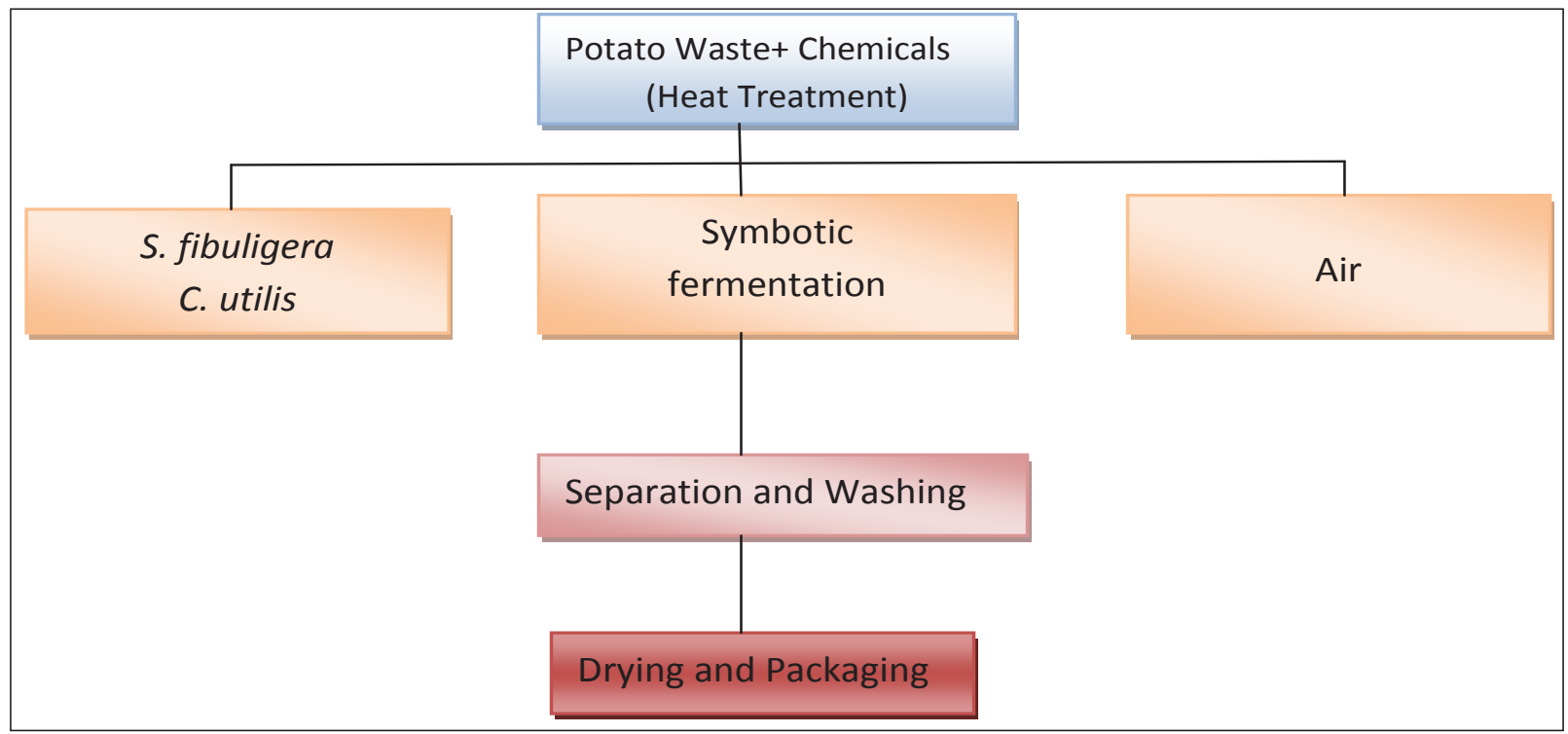

Fig. 7: Utilization of the potato waste for the symba yeast production

the goats were fed cauliflower (529 $\mathrm{g}$ DM/day and 87.5 g/day, respectively). In Exp. 2 total intake of cabbage and concentrate was similar (484 g and 453 g DM/day) whether the goats were fed 100 or 200 $\mathrm{g}$ concentrate/day but lower than that of Para grass and concentrate probably due to the low DM content of the cabbage $(5.9 \%)$. Crude protein intake (79 $\mathrm{g}$ to $86 \mathrm{~g} /$ day) and body weight gain (70 g to $88 \mathrm{~g} /$ day) was not significantly different between treatments. Adding concentrate consequently resulted in higher DM intake than in Exp. 1 but did not result in any higher growth rate. Weight of livers from goats fed cabbage was about $90 \mathrm{~g}$ higher than from goats fed Para grass but no pesticide/herbicide residues were found in meat or liver.

Factors limiting the use of feed from waste in feed formulation

\section{Nutritional aspects}

- Variability in nutrient level and quality (soil, climate [temperature, rain], variety, harvest method, processing). 
- Presence of naturally occurring anti-nutritional and/or toxic factors (alkaloids, non-starch polysaccharides, glycosides, tartrates, heavy metals).

$\square$ Presence of pathogenic micro-organisms (Salmonellae: present if waste is not processed/ sterilised properly).

- Need for supplementation (minerals, most limiting essential amino acids) (wine, apple dates; duration of transport).

- Bulkiness, wetness and/or powdery texture (need for pelleting) (brewers' spent grains; poultry manure, sludge; potato starch).

- Processing requirements (drying detoxification) (availability of machinery; knowledge of processing; energy source).

L Lack of research and development efforts (feed industries) (co-operation developed/developing countries; transfer of knowledge).

\section{Technical aspects}

- Seasonal and unreliable supply (need for storage) (wine, apple, dates; duration of transport).

B Bulkiness, wetness and/or powdery texture (need for pelleting) (brewers' spent grains; poultry manure, sludge; potato starch).

口 Processing requirements (drying, detoxification) (availability of machinery; knowledge of processing; energy source).

$\square$ Lack of research and development efforts (feed industries) (co-operation developed/developing countries; transfer of knowledge).

Sources: Boushy and Poe (2001).

In fruit juice processing large amounts of water are used, mainly for cleaning purposes. Due to hygienic and food safety considerations, most of the utilized water is drinking water quality and the amount of water effluent can be up to $10 \mathrm{~m}^{3} /$ tonnes of raw material. The water is used for raw material washing, plant and equipment cleaning, and other industrial utilization. The resultant wastewater has a high organic content, containing parts of the fruits, cleaning agents, salts and suspended solids.

As the amount and quality of the effluent greatly influences the economic feasibility of a company, efforts should be made to minimize the use of water and therefore to (World Bank, 1996): use dry methods such as vibration or air jets to clean raw fruit; separate and re-circulate process wastewaters; minimize the use of water for cleaning purposes; remove solid wastes without the use of water; and use countercurrent systems where washing is necessary.

Solid wastes usually originate from pre-treatment washing and sorting and they consist of damaged fruits, stems and stalks. A major source of solid waste generation is the pressing process, in which peels, seeds, pulps are separated from the fruit juice. There is a large unused potential in the juice processing wastes, as they contain a sizeable amount of healthy substances, such as flavonoids, colours and pectins.

\section{CONCLUSION AND FUTURE THRUST}

Food processing industry including fruit and vegetable processing is the second largest generator of wastes into the environment only after the household sewage. The generation of biodegradable waste, increased linearly with the growth and development of food processing industry. A huge amount of waste in the form of liquid and solid is produced in the fruit and vegetable processing industries are valuable and biodegradable natural resources with large economic potential but causes pollution problem if not utilized or disposed off properly. The waste obtained from fruit processing industry is extremely diverse due to the use of wide variety of fruits and vegetables, the broad range of processes and the multiplicity of the product. Different fruits and vegetable possess various quantities of waste. Chemical composition of the wastes from fruits and vegetables revealed that it is a rich source of various nutrients. So throwing the waste from food processing industries into the river is virtually throwing coins into the sea. Some of these fruit and vegetable wastes are a rich source of vital constituents like carbohydrates, proteins, fats, 
minerals, fibers etc. The Biological Oxygen Demand (BOD), Chemical Oxygen Demand (COD) and $\mathrm{pH}$ of some of the fruit and vegetables wastes ranged from 78-65,000 (mg/L), 43-41,000 (mg/L) and 3.1-11.9, respectively. A number of value added products such as essential oils, starch, pectin, dietary fibers, acids, wine, ethanol, vinegar, microbial pigments, flavours and gums, enzymes, single cell proteins, amino acids, vitamins, organic compounds, colours and animal feed can be made out of the waste from processing industries. Waste product which is thrown into the environment has a very good antimicrobial and antioxidant potentiality. These are novel, natural and economic sources of antimicrobics and antioxidants, which can be used in the prevention of diseases caused by pathogenic microbes. These all benefits will open up as a scope for future utilization of the waste for therapeutic purpose. However, lack of pilot testing of the developed technologies, negative attitude of the industrialists and perhaps, less helping hand from the government sector have led to virtually no adoption of the technologies developed for the waste utilization. The future should be the utilization of the waste for recovery of various byproducts which should be stabilized and economic in processing. Encouragement of the food industries in the form of some incentives and concession at global level should be done for setting up waste utilization plants. Nevertheless, when industrialists will come to know about the economic potential of such units, they will themselves come forward. In future, there is a need of an integrated approach comprising stripping-off the useful recoverable products followed by waste treatment technology. A number of techniques (genetic engineering reverse osmosis, enzyme technology etc) can be used to improve the production of useful products from wastes. Transfer of technology from the research institutes to user industry is almost negligible and need to be taken up as future area of effective action. Lastly, all these are being subjected to increased scrutiny by environmental regulations often with valid reasons. Decision making in residues disposal source reduction is undoubtedly the best path to follow in directing future policy.

\section{REFERENCES}

Anonymous, 1977. Olive canner fined for pits: making boilers fuel. Conner Paclur, 1977.

Anonymous, 1979. Trivalley fries boiler with peach pits. Processed Prepared Foods 33.

Aref, H.L., Salah, K.B.H., Chaumont, J.P., Fekih, A.W., Aouni, M. and Said, K. 2010. In vitro antimicrobial activity of four Ficus carica latex fractions against resistant human pathogens. Pakistan Journal of Pharmaceutical Sciences, 23: 53-58.

Arrianitiyannis, I.S., Ladas, O. and Mavromatis, A. 2006. Wine waste treatment methodology. Int. J. Food Sci. Tech., 41(10): 1117-1151.

Arrianitiyannis, I.S. 2008. Waste management for food industries. Elsevier, Amsterdam, The Netherlands.

Arumugam, R. and Manikandan, M. 2011. Fermentation of Pretreated Hydrolyzates of Banana and Mango Fruit Wastes for Ethanol Production. Asian J. Exp. Biol. Sci., 2(2): 246-256.

Badger, P.C. and Brodwer, D.J. 1989. Ethanol production from food processing waste. Hort. Sci., 24(2): 227.

Bahar, S. and Azueze, J.T. 1984. Studies on the growth of Fusarium sp on citrus waste for production of single cell protein. J. Food Sci. Tech., 21(2): 63.

Bath, D.L. 1981. Feed by-products and their utilization by ruminants. In: Upgrading Residues and By Products for Animals. Thuber J (ed.) CRC Press, Inc.

Bendini, A., Cerretani, L., Pizzolante, L., Toschi, T.G., Guzzo, F., Ceoldo, S., Marconi, A.M., Andreetta, F. and Levi, M. 2006. Eur. Food Res. Tech., 223: 102-109.

Bhalerao, S.D., Mulsmuky, G.V., Anthanthakishna, S.M. and Potty, V.H. 1989. Effluent management in food industry. Indian Food Packer, 43(2): 5.

Bhalla, T.C. and Joshi, M.C. 1994. Protein enrichment of apple pomace by co-culture of cellulolytic moulds and yeasts. Worlds J. Microbiol. Biotechnol., 10(1): 116.

Boca Raton, F.L., Beerh, O.P., Raghuramaiah, B. and Krishnamurthy, G.V. 1976. Utilization of mango waste peel as a source of pectin. J. Food Sci. Technol., 13(2): 96.

Boucque, C.V. and Fiems, L.O. 1988. Vegetable by-products of agro-industrial origin. Livestock Prod. Sci., 19: 97-135.

Campo, Id., Alegria, I., Zazpe, M., Echeverria, M. and Echeverria, I. 2006. Diluted acid hydrolysis pretreatment of agri-food wastes for bioethanol production. Indust. Crops and Prod., 42: 214221.

Chaliha, B.P., Barua, A.D., Gohain, A. and Siddapa, G.S. 1963. Assam lemon as a source of pectin. Part I. Effect of method of extraction, drying and storage of peels and pomace on the recovery and quality of pectin. Indian Food Packer, 17(3): 8. 
Cohn, R. and Cohn, L. 2001. By-products of fruit processing. In: Fruit Processing: Nutrition Products and Quality Management. Arthey D \& Ashurt PR (eds). Aspean Publication, Maryland, pp. 225-245.

Costa, E.S., Hiruma-Lima, C.A., Lima, E.O., Sucupira, G.C., Bertolin, A.O., Lolis, S.F., Andrade, F.D.P., Vilegas, W. and Souza-Brito, A.R.M. 2008. Antimicrobial activity of some medicinal plants of the Cerrado, Brazil. Phytotherapy Research, 22: 705-707.

Das, N.B. and Banerjee, R.M. 1952. Utilization of mango seed kernel as source of starch. Science Culture, 17: 33.

Directorate of Marketing and Inspection, 1958. Ministry of food and agriculture report.. Govt. of India, Nagpur.

Eliot, D.C., Baker, E.G., Butner, R.S. and Seebok Ir L.J. 1993. Bench scale reactor tests of low temperature, catalytic gasification of wet industrial wastes. Transaction of the ASMME. J. Solar Energy Engg., 115: 53.

Essien, J.P., Akpan, E.J. and Essien, E.P. 2005. Studies on mould growth and biomass production using waste banana peel. Bioresource Technol., 96: 14511456.

FAO (Food and Agricultural Organization of the Unites Nations). FAOSTAT statistics data base,Agriculture, Rome, Italy. 2003.

Flickiger, M.C. and Tsao, G.T. 1978. Ann. Rep. Ferment Process, 2: 23.

Fluit, A.C., Visser, M.R. and Schmitz, F.J. 2001. Molecular detection of antimicrobial resistance. Clinical Microbiology Reviews, 14: 836-871.

Gera, I.B. and Kramer, A. 1969. The utilization of food industries westes In: Advances in Food Research, Chichester CO, Mark EM \& Stewart GF (eds.), Academic Press, New York, London, pp. 28

Ghanem, K.M. 1992. Single cell protein production from beet pulp by mixed cultures. Microbiologia, 8(1): 39 .

Girujie, O., Popav, S. and Gacesa, S. 1992. Microbiologia, 29: 41.

Gray, S.T. 2006. Food waste management and value added products. J. Food Sci., 69(3): 102-104.

Gray, W.D. and Abou-el-Seound, M.O. 1966. Fungal protein for food and feed IV whole sugar beets on beet pulp as a substrate. Econ. Bot., 20: 372.

Grohmann, K., Baldwin, E.A. and Buslig, B.S. 1994. Production of ethanol form enzymatic hydrolysed orange peel by the yeast Saccharomyces cerevisiae. Appl. Biochem. Biotechnol., 45/46: 315.

Gross, J. 1977. In: Citrus Science and Technology Vol. 2. Negy S, Show PE \& Veldhuis MK (eds.) AVI Pub. Westport CT, pp. 302.

Guneseelan, N.V. 2004. Biochemical methane potential of fruits and vegetables solid waste feedstocks. Biomass and Bioenergy, 26: 389.
Gupta, K. and Joshi, V.K. 2000. Fermentative utilization of waste from food processing industry. In: Post-harvest Technology of Fruits and Vegetables: Handling Processing Fermentation and Waste Management, Vol. 2. Verma LR \& Joshi VK (eds). Indus Pub Co, New Delhi, pp. 1171-1193.

Gupta, R., Chauhau, T.R. and Lall, D. 1993. Nutritional protential of vegetable waste products for ruminants. Biores. Technol., 44: 263-265.

Hakkinen, S., Heinonen, M., Karenlampi, S., Mykkanen, H., Ruuskanen, J. and Torronen, R. 1999. Screening of selected flavonoids and phenolic acids in 19 berries. Food Res. Int., 32(5): 345-353.

Hammer, M.J. and Hammer, MJJr. 2004. Water and Waste Technology. Pearson Educational International. $5^{\text {th }}$ Edition, New Jersey, pp. 388-437.

Hammond, J.B., Egg, R., Diggins, D. and Coble, C.G. 1996. Alcohol from bananas. Bioresource Technol., 56: 125130.

Hang, Y.D., Splittstoesser, O.F., Woodams, E.E. and Scherman R.M. 1977. Citric acid fermentation of brewery waste. J. Food Sci., 42: 383.

Hang, Y.D., Splittstoesser, O.F. and Woodams, E.E. 1975. Utilization of brewery spent grain liquor by Aspergillus niger. Appl. Microbiol., 30: 879.

Hang, Y.D. 1988. Improvement of nutritional value of apple pomace by fermentation. Nutr. Rep. International, 38(1): 207.

Hang, Y.D. and Walters, R.H. 1989. Treatment and utilization of apple processing wastes. In: Processed Apple Products, Downing DL (ed.) AVI Van Nostand Reinhold, New York, pp. 365.

Hang, Y.D. and Woodams, E.E. 1977. Baked beans waste: potential substrate for producing amylase. Appl. Environ. Microbiol., 33: 1293.

Hang, Y.O., Splilttstoesser, O.F. and Landschoot, R.L. 1972. Sauerkraut waste: A favorable medium for cultivating yeasts. Appl. Microbiol., 24: 1007.

Harrison, R.M. 2001. Pollution causes, effect and controls. Royal Society of Chemistry UK.

Hills, D.J. and Roberts, D.W. 1982. Conversion of tomato peel and honeydew solid waste into methane gas. Transaction of the ASAE, 25(30): 820.

Huber, J.T. 1981. Upgrading residues and by products for animals. CRC Press Inc. Boca Raton F L.

Iacopini, P., Baldi, M., Storchi, P. and Sebastiani, L. 2008. J. Food Compos Anal., 21: 589- 598.

Imire, F.K.E. and Vlitos, A.J. 1975. In: Single cell protein II, Tannenbaum SR \& Wang D (eds.) MIT Press, Cambridge, pp. 223.

Jacob, R., Hasegawa, S. and Manners, G. 2000. Perishables Handling Quarterly, 102: 6-8.

Jayaprakasha, G.K., Selvi, T. and Sakariah, K.K. 2003. Antibacterial and antioxidant activities of grape (Vitis 
vinifera) seed extracts. Food Research International, 36: 117122.

Johar, D.S., Krishnamurthy, G.V. and Bhatia, B.S. 1960. Utilization of apple pomace. Food Sci., 9: 82.

Joshi, C. and Joshi, V.K. 1990. Food processing management technology: Need for integrated approach. Indian Food Packer, 44(5): 56.

Joshi, V.K., Attri, D., Bala, A. and Bhushan, S. 2003. Microbial pigments. Ind. J. Biotechnol., 2: 362.

Joshi, V.K., Dev Raj and Joshi, Chetan. 2011. Utilization of wastes from food fermentation industry. In: Food Processing Wastes Management. New India Publishing Agency, Pitam Pura, New Delhi, pp. 295-356.

Joshi, V.K., Gupta, K., Devrajan, A., Lal, B.B. and Arya, S.P. 2000. Production and evaluation of fermented apple pomace in the feed of broilers. J. Food Sci. Technol., 37(6): 609.

Joshi, V.K., Pandey, A. and Sandhu, D.K. 1999. Food Factory Waste Management Technology. In: Biotechnology: Food Fermentation, Vol. II. Joshi VK \& Pandey A (eds.) pp. 12911348. Educational Publishers and Distributors, New Delhi.

Joshi, V.K., Rana Neerja and Devi Mutum. Preema 2009. Technology for utilization of apple pomace: A waste from apple juice processing industry. Indian Food Industry, 28(4): 1-10.

Joshi, V.K., Walia, Abhishek and Rana S. Neerja. 2011. Production of Bioethanol from Food Industry Waste: Microbiology, Biochemistry and Technology. In: "Bioenergy production from Waste. Eds. C. Bhasker, Springer, Berlin, pp. 251-302.

Joshi, V.K. 2002. Food Processing Waste Management oppurtunities and challenges. In: Biotechnology in Agriculture and Enviornment. J.K. Arora, S.S. Marwaha and R. Grover. (Eds.) pp. 129-148. Asia Tech Publishers and Distributors, New Delhi.

Joshi, V.K. and Attri, D. 2005. Optimization of apple based medium and fermentation conditions for pigment production by Rhodotorula species. Proc. Nat. Acad. Sci. India, 76B: 171.

Joshi, V.K. and Bhutani, V.P. 1995. Peaches and nectarines. In: Handbook of fruit science and technology D.K. Salunkhe and S.S. Kadam. Marcel Dekker, New York, pp. 243.

Joshi, V.K. and Dev Raj. 2010. Biotechnology in waste management. In: Food Biotechnology: Principles and Practices. Joshi, V.K. and Singh, R.S.(Eds). IK International Publishing House. New Delhi, pp. 881-914

Joshi, V.K. and Lal, B.B. 1998. Food processing waste management : Opportunities and Challenges. Presented in Biotechnology in Agriculture and Environment organised by PSCST, Chandigarh and DBT, New Delhi, pp. 31.
Joshi, V.K. and Rana, N. 2008. Microbial technology for the production of value added products from apple pomace. In: Agriculturally Important Microorganisms Vol II. Khachatourians GG, Arora DK, Rajendra TP \& Shrivastava AK (eds), Academic Worlds International, pp 271.

Joshi, V.K. and Sandhu, D.K. 1996. Preparation and evaluation of animal feed using solid state fermentation of apple pomace. Bioresource Technol., 56: 251.

Joshi, V.K. and Sharma, J.K. 1989. Preliminary studies on utilization of waste from wine fermentation as a pollen substitute for Honey bees. Ibid.

Joshi, V.K. and Sharma, S.K. 2011. Food Processing Industrial Wastes: Present Scenario. In: Food Processing Wastes Management. New India Publishing Agency, Pitam Pura, New Delhi, pp. 1-31.

Joshi V.K. and Sharma, S.K. 2011. Food Processing Wastes Management. New India Publishing Agency, Pitam Pura, New Delhi, pp. 472.

Kabuki, T., Nakajima, H., Arai, M., Ueda, S., Kuwabara, Y. and Dosako, S. 2000. Characterization of novel antimicrobial compounds from mango (Mangifera indica $\mathrm{L}$ ). kernel seeds. Food Chemistry, 71: 61-66.

Kahlon, S.S. and Arora, M. 1986. Utilization of potato peels by fungi for protein production. J. Food Sci. Technol., 23(5) : 264.

Kaneria, M., Baravalia, Y., Vaghasiya, Y., Chanda, S. 2009. Determination of antibacterial and antioxidant potential of some medicinal plants from Saurashtra region, India. Indian Journal of Pharmaceutical Sciences, 71: 406-412.

Kanna, J., Ben-Shelam, V. and River, O. 1984. Proceeding of international federation of fruit juice producers, 18: 219.

Kjeldsen, P., Bariaz, M.A., Rooker, A.P., Baun, A., Lendin, A. and Chistensen, T.H. 2002. Crit. Rev. Environmental Sci. Technol., 32: 297-336.

Knekt, P., Jarvinen, R., Seppanen, R., Heliovaara, M., Teppo, L., Pukkala, E. and Aromaa, A. 1997. Dietary flavonoids and the risk of lung cancer and other malignant neoplasms.

Knol, W., Vander Most, M.D. and De Waart, J. 1978. Biogas production by anaerobic digestion of fruit and vegetables wastes. J. Food Sci. Agric., 29: 822.

Lilly, V.G., Wilson, H.A. and Leach. 1958. J. Appl. Microbiol., 6: 105.

Long, S.K. and Patrick, R. 1961. Production of 2,3 butylene glycol from citrus waste. Appl. Microbiol., 9: 244.

Lu, Y. and Foo, L. 2000. Food Chem., 68: 81-85.

Maini, S.B. and Sethi, V. 2000. Utilization of fruits and vegetable processing waste. In: Post-harvest Technology of Fruits and Vegetables: handling processing fermentation and waste management. Verma LR \& Joshi VK (eds) Indus. Publishing Co., New Delhi Vol. 2, pp.1006. 
Mani Lal, V.B., Naryanan, C.S. and Balagopalan, C. 1991. Cassava starch effluent treatment with concomitant SCP production. World J. Microbiol. Biotechnol., 7(2): 185.

Marwaha, S.S. and Arora, J.K. 1999. Production of gum amino acid and vitamins. In: Biotechnology: Food Fermentation. Vol-II. Joshi VK \& Pandey A (eds.). Educational Publisher and Distributors, New Delhi, pp.1231.

Masuda. 1964. Studies on fermentative processing of apple fruit. Fermentation of milled apple pulps in cider making. J. Ferment. Technol., 42: 379.

Mazza, G. and Miniati, E. 1993. Anthocynanins in fruits, vegetable and grains. CRC Press, Boca Raton FL.

Miyake, Y., Yamamoto, K., Morimitsu, Y. and Osawa, T. 1997. J. Agric. Food Chem., 45: 4619-4623.

Morris, C.E. 1985. Apple and pear fiber. Food Engg., 72.

Nair, P.M. 1994. Biotechnology and Hi-technology in food production processing and preservation industry and export opportunities. Indian Food Ind., 13(1): 18.

Nand, K. 1994. Biogas from food wastes. Indian Food Industry, 13(3): 22.

Nicolini, L.V., Nolstein, V.J. and Cirilli, C.S. 1987. Solid state fermentation of orange peel grape stalks by Pleutrotus osteatus, Agroybe aegerita and Armillariella mellea. Appl. Microbial. Biotechnol., 26: 25.

Nigam, P. 1990. Investigation of some factors important for solid state fermentation of sugar cane baggasse for animal feed production. Enzyme Microb. Technol., 12: 808.

Nigam, P. and Singh, D. 1996. Processing of agriculture waste in solid state fermentation for microbial protein production. J. Sci. Ind. Res. 55- special issue. Publication of Information Directorate, New Delhi.

Onwuka, C.F.I., Adetiloye, P.O. and Afolami, C.A. 1997. Use of household wastes and crop residues in small ruminant feeding in Nigeria. Small Ruminant Research, 24: 233237.

Palaniswamy, K.P., Muthukrishnan, C.R. and Shanamugavellu, K.G. 1974. Physico-chemical characteristics of some varieties of mango. Indian Food Packer, 28(5): 12.

Prasad, K.N., Xie, H., Hao, J., Yang, B., Qiu, S., Wei, X., Chen, F. and Jiang, Y. 2010. Antioxidant and anticancer activities of 8 - hydroxypsoralen isolated from wampee [Clausena lansium (Lour.) Skeels] peel. Food Chemistry, 118: 62-66.

Pruthi, J.S., Mookerji, K.K. and Lal, G. 1960. A study of factors affecting the recovery and quality of pectin from guava. Indian Food Packer, 14(7): 7.

Rabe, T. and Van Staden, J. 1997. Antibacterial activity of South African plants used for medicinal purposes. Journal of Ethanopharmacology, 56: 81-87.

Rahmat, H., Hodge, R.A., Manderson, G.J. and Yu, P.L. 1995. Solid substrate fermentation of Kloekera apiculata and Candida uitilis on apple pomace to produce on improved state feed. World J. Microbiol. Biotechnol., 11(2): 168.
Rajaei, A., Barzegar, M., Mobarez, A.M., Sahari, M.A. and Esfahani, Z.H. 2010. Antioxidant, antimicrobial and antimutagenicity activities of pistachio (Pistachia vera) green hull extract. Food Chemistry and Toxicology, 48: 107112.

Rauha, J.P., Remes, S., Heinonen, M., Hopia, A., Kahkonen, M., Kujala, T., Pihlaja, K., Vuorela, H. and Vuorela, P. 2000. Antimicrobial effects of Finnish plants extracts containing flavonoids and other phenolic compounds. Int. J. Food Microbio., 56(1): 3-12.

Sakellaris, G., Nikolaropoulos, A.S. and Evangelopoulos, A.E. 1988. Po-lygalacturonase biosynthesis by Lactobacillus plantarum ef-fect of cultural conditions on enzyme production, J. Appl. Bacteriol., 65: 397-404.

Sandhu, D.K. and Joshi, V.K. 1996. Development of apple pomace medium optimization of condition of pigment production by Rhodotorula. Adv Food Res., 19(1/2): 31.

Schroeder, J.W. 1999. By-products and regionally available alternative feedstuffs for dairy cattle. North Dakota State University. NDSU Extension Service. http://www.ext. nodak. edu/extpubs/ansci/dairy/as1180w.html.

Shah, G.H. and Masoodi, F.A. 1984. Studies on utilization of wastes from apple processing plants. Indian Food Packer, 48(50: 47.

Shukla, J.P. and Dutta, S.M. 1967. Production of fungal protein form waste molasses. Indian J. Technol., 5: 27.

Simons, G., Johannis, M. and Miller, W. 1994. Institution issues facing California biomass energy industry and role a collaborative. Bio-energy 94, Proceedings of sixth National Bio-energy Conference. Reno/ sparks, NV, pp. 547.

Singh, R.P., Murthy, K.N.C. and Jayaprakasha, G.K. 2002. Studies on the antioxidant activity of pomegranate (Punica granatum) peel and seed extracts using in vitro models. Journal of Agricultural and Food Chemistry, 50: 81-86.

Skogman, H. 1976. Production of symba-yeast from potato waste: In: Food From Waste, Birch GG, Parkar KJ \& Worgan JT (eds.) Applied Science Pub., London.

Souquet, J.M., Cheynier, V., Brossaud, F. and Moutounet, M. 1996. Phytochemistry, 43: 509-512.

Srirangrajan, A.N. and Shrikhande, A.J. 1977. Characterization of mango peels pectin. J. Food Sci., 42: 279.

Srivas, S.L. and Pruthi, J.S. 1976. Studies on the quantitative estimation of chemical components of cashew apple, citrus and other fruit pectin. J. Inst. Chemists (India), 48: 95.

Subramanyam, V., Lal, G., Bhetil, G.S., Jain, NL., Bains, G.S., Srinath, K.V., Anandaswamy, B., Krishna, B.H. and Lakshmi Narayanan, S.K. 1957. Studies on banana pseudo-stem starch. Production yield, physio-chemical properties and uses. J. Sci. Food Agric., 8: 253.

Sundsfjord, A., Simonsen, G.S., Haldorsen, B.C., Haaheim, H., Hjelmevoll, S.O., Littauer, P. and Dahl, K.H. 2004. Genetic 
methods for detection of antimicrobial resistance. Acta Pathologica, Microbiologica et Immunologica Scandinavica, 112: 815-837.

Tannenbaum, S.R. and Wang, D.I.C. 1975. Single cell protein vol.-II. MIT press, Cambridge, Mass.

Ting, S.V. and Herdrickson, R. 1969. Food Tech., 23(7): 947.

Torres, J.L. and Bobet, R. 2001. J. Agr. Food Chem., 49: 46274634.

Trehan, K. 1990. Energy from microbial and other sources. In: Biotechnology, Wiley Eastern, New Delhi, pp. 286.

Van Den Broeck, I., Ludikhuyze, L.R., Weemaes, C.A., Van Loey, A.M. and Hendrickx, M.E. 1999. Thermal inactivation kinetics of pectin esterase extracted from oranges, J. Food Process Preserv., 23: 391-406.

van der Sluis, A.A., Dekker, M., Skrede, G. and Jongen, W.M.F. 2002. J. Agr. Food Chem., 50: 7211-7219.
Walter, R.H., Rao, M.A., Sharman, R.M. and Cooley, H.J. 1985 Edible fibers from apple pomace. J. Food Sci., 56: 747-749.

Whiting, K.J. 2001. Proceeding of the $3^{\text {rd }}$ International symposium on waste treatment technologies, Brussels. Institution of chemical engineers publication, Rugby 1, 13.

William, P.T. 2005. Water treatment and disposal. John Wally (eds.) Greet Britain, pp. 9.

Wright, J. 1995. In: food flavouring. Ashurst PR (ed). Black A \& P, Elasgow, Scotland, pp. 24.

Wyman, Ch. E. 2001. Twenty years of trials, tribulations, and research progress in bioethanol technology. Appl. Biochem. Biotech., 91: 521.

Zhang, P., Whistler, R.L., BeMiller, J.N. and Hamaker, B.R. 2005. Banana starch: Production, physicochemical properties, and digestibility a review. Carbohydrate Polymers, 59: 443 458. 